\title{
Temporal and spatial variability of dissolved organic and inorganic phosphorus, and metrics of phosphorus bioavailability in an upwelling-dominated coastal system
}

\author{
Kathleen C. Ruttenberg \\ Department of Oceanography and Department of Geology and Geophysics, School of Ocean and Earth Science and \\ Technology (SOEST), University of Hawaii, Honolulu, Hawaii, USA
}

Sonya T. Dyhrman

Department of Biology, Woods Hole Oceanographic Institution, Woods Hole, Massachusetts, USA

Received 7 December 2004; revised 27 June 2005; accepted 9 September 2005; published 27 October 2005.

[1] High-frequency temporal and spatial shifts in the various dissolved P pools (total, inorganic, and organic) are linked to upwelling/relaxation events and to phytoplankton bloom dynamics in the upwelling-dominated Oregon coastal system. The presence and regulation of alkaline phosphatase activity (APA) is apparent in the bulk phytoplankton population and in studies of cell-specific APA using Enzyme Labeled Fluorescence $\left(\mathrm{ELF}^{\mathrm{B}}\right)$. Spatial and temporal variability are also evident in phytoplankton community composition and in APA. The spatial pattern of dissolved phosphorus and APA variability can be explained by bottom-controlled patterns of upwelling, and flushing times of different regions within the study area. The presence of APA in eukaryotic taxa indicates that dissolved organic phosphorus (DOP) may contribute to phytoplankton $\mathrm{P}$ nutrition in this system, highlighting the need for a more complete understanding of $\mathrm{P}$ cycling and bioavailability in the coastal ocean.

Citation: Ruttenberg, K. C., and S. T. Dhyrman (2005), Temporal and spatial variability of dissolved organic and inorganic phosphorus, and metrics of phosphorus bioavailability in an upwelling-dominated coastal system, J. Geophys. Res., 110, C10S13, doi:10.1029/2004JC002837.

\section{Introduction}

[2] Phosphorus (P) is an essential macronutrient for all phytoplankton. There is a growing body of evidence indicating that $\mathrm{P}$ can play an important role in supporting phytoplankton production, at times limiting productivity in various open ocean and coastal marine environments [Ammerman et al., 2003; Karl et al., 2001; Karl and Björkman, 2002; Krom et al., 1991; Monaghan and Ruttenberg, 1999; Palenik and Dyhrman, 1998; Wu et al., 2000]. These and other studies highlight the importance of $\mathrm{P}$ bioavailability, and suggest a pivotal role for dissolved organic phosphorus (DOP) in influencing primary production and ecosystem dynamics.

[3] Although dissolved inorganic phosphate (DIP) is typically considered the most bioavailable $\mathrm{P}$ source, numerous studies have demonstrated the ability of phytoplankton to use DOP as a source of P (e.g., reviewed by Cembella et al. [1984] and recently discussed by Karl and Björkman [2002] and Björkman and Karl [2003]). DOP concentration can exceed DIP in coastal and open ocean surface waters [e.g., Butler et al., 1979; Jackson and Williams, 1985; Karl and Björkman, 2002; Monaghan and Ruttenberg, 1999; Orrett and Karl, 1987; Wu et al., 2000] (also this study),

Copyright 2005 by the American Geophysical Union. 0148-0227/05/2004JC002837\$09.00 and thus has the potential to play an important role in supporting phytoplankton productivity.

[4] Historically, there has been a disproportionate emphasis on dissolved inorganic nutrients, both in the large oceanographic survey programs that have compiled vast regional nutrient data sets (e.g., GEOSECS, TTO (see Ocean Atlas website, http://odf.ucsd.edu/Ocean Atlas/ aos.html), TOGA-CORE (see data center website, http:// cdiac.esd.ornl.gov/), US-JGOFS (see USJGOFS protocols website, http://usjgofs.whoi.edu/protocols.html; note that JGOFS time series sites have included measurements of dissolved organic nutrients), and in smaller-scale studies. This can be attributed to three factors: (1) considerably more effort is required to measure dissolved organic nutrients than to measure their inorganic counterparts, (2) a lack of community consensus on the best methods for measuring dissolved organic nutrients, and (3) a failure to appreciate that the dissolved organic nutrient pools can play an active and important role in phytoplankton nutrition. This latter notion is being reversed, as numerous studies now recognize that the organic component of the nutrient pools, both $\mathrm{P}$ and nitrogen $(\mathrm{N})$, can play important roles in supplying $\mathrm{P}$ and $\mathrm{N}$ to primary producers. However, our understanding of the biogeochemistry and bioavailability of the dissolved organic nutrient pools, particularly $\mathrm{P}$, remains in its infancy, and many important questions remain. 


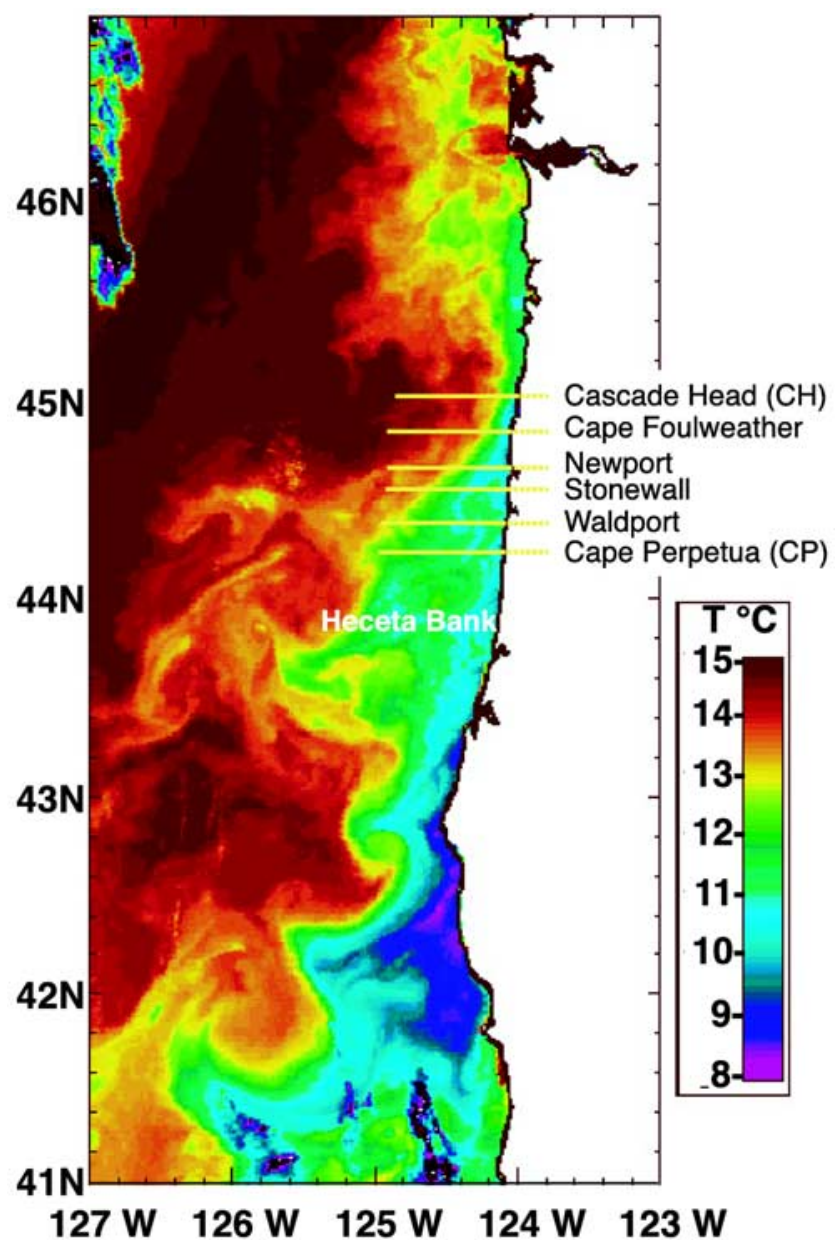

Figure 1. Satellite sea surface temperature (SST) image (COAST web site, http://damp.oce.orst.edu/coast/) illustrating typical SST distribution during the spring-summer upwelling season on the Oregon coast. Colder temperatures hugging the coast are indicative of upwelled cold, nutrient rich waters, while warmer surface waters offshore reflect solar warming as surface waters are advected away from the near-coastal region of active upwelling. The distribution of cold, upwelled water reflects coastline bathymetry (see text). Transect lines occupied for high vertical resolution sampling during the COAST-1 cruise are superimposed on the satellite SST image.

[5] In this study, we target some of the unanswered questions about DOP in the coastal ocean, including: (1) How dynamic is the DOP pool in space and time? (2) How do DIP and DOP dynamics compare? (3) What are the timescales and magnitudes of DIP and DOP variability? (4) What are the physical and biological controls on DIP and DOP variability? (5) What is the degree of spatial and temporal variability in metrics of DOP bioavailability as evidenced by whole community cell-bound and single-cell activity assays of the DOPhydrolyzing enzyme, Alkaline Phosphatase (APase)?

[6] We present results from the first of three cruises in the Oregon coastal upwelling region (Figure 1), conducted as part of the Coastal Ocean Processes (CoOP)-funded Coastal
Advances in Shelf Transport (COAST; http://damp.oce. orst.edu/coast) project. High-resolution sampling, in both space and time, reveal substantial spatial and temporal variability in DOP and DIP in surface water and in depth profiles along study transects. The physical and biological driving forces behind the observed variability are described, and evidence for DOP bioavailability, in the form of whole community and cell-specific alkaline phosphatase activity (APA), is presented.

\section{COAST Program: Overview and Study Site Description}

[7] The COAST project is a 5-year, multidisciplinary, multi-PI program funded by the CoOP program to investigate seasonal patterns of circulation, biology, and chemistry in the Oregon coastal ocean, as part of the CoOP mandate to advance the understanding of biogeochemistry in coastal systems dominated by wind-driven transport processes. The over-arching goal of the COAST program is to evaluate the dependence of biological and biogeochemical parameters on physical circulation, particularly upwelling, downwelling (relaxation of upwelling), alongshore and cross-shelf transport. Primary objectives of the COAST project are to determine the sources of both organic and inorganic nutrients, the response of the biological community to the timing and pattern of nutrient delivery, and to track the cross-shelf transport of nutrients (inorganic and organic) and particulate organic matter.

[8] The COAST sampling grid is located off the Oregon Coast, extending from $\sim 45.2^{\circ} \mathrm{N}$ to $43.7^{\circ} \mathrm{N}$, and from shallow inshore stations ( $\sim 30 \mathrm{~m}$ water depth) to offshore stations ( $\sim 1000 \mathrm{~m}$ water depth) (Figures 1 and 2$)$. This coastal area is characterized by frequent upwelling-relaxation events during spring and summer [Barth et al., 2005; Castelao and Barth, 2005]. Satellite sea surface temperature (SST) images show upwelled colder deeper waters cropping out at the surface near the coastline (Figure 1). The pattern of colder surface waters during upwelling events closely tracks the bathymetry, with a narrow band of cold, upwelled water in the northern part of the field area where the shallow shelf is narrow and bathymetric lines run parallel to the coastline (vicinity of Cascade Head), and a broader band of cold, upwelled water over Hecata Bank, where the shelf broadens out into a shallow platform and bathymetric lines bulge out over the bank (Figures 1 and 2).

[9] High-resolution sampling was conducted using two ships simultaneously. One ship conducted rapid, highresolution surveys of the three-dimensional thermohaline, bio-optical, zooplankton and velocity fields [Barth and Wheeler, 2005; Barth et al., 2005]. A second ship, operating within the same region, conducted high vertical resolution profiling of water properties (temperature, salinity, turbulence, nutrients (inorganic and organic), chlorophyll $a$, phytoplankton photosynthesis parameters, particulate and dissolved organics, trace metals) [Barth and Wheeler, 2005; Hales et al., 2005; Karp-Boss et al., 2004]. Samples described here were collected on the high vertical resolution sampling ship, the R/V Thomas G. Thompson, which focused primarily on two regions: the northern region $(\mathrm{CH}$ line) of relatively simple bathymetry and the southern 

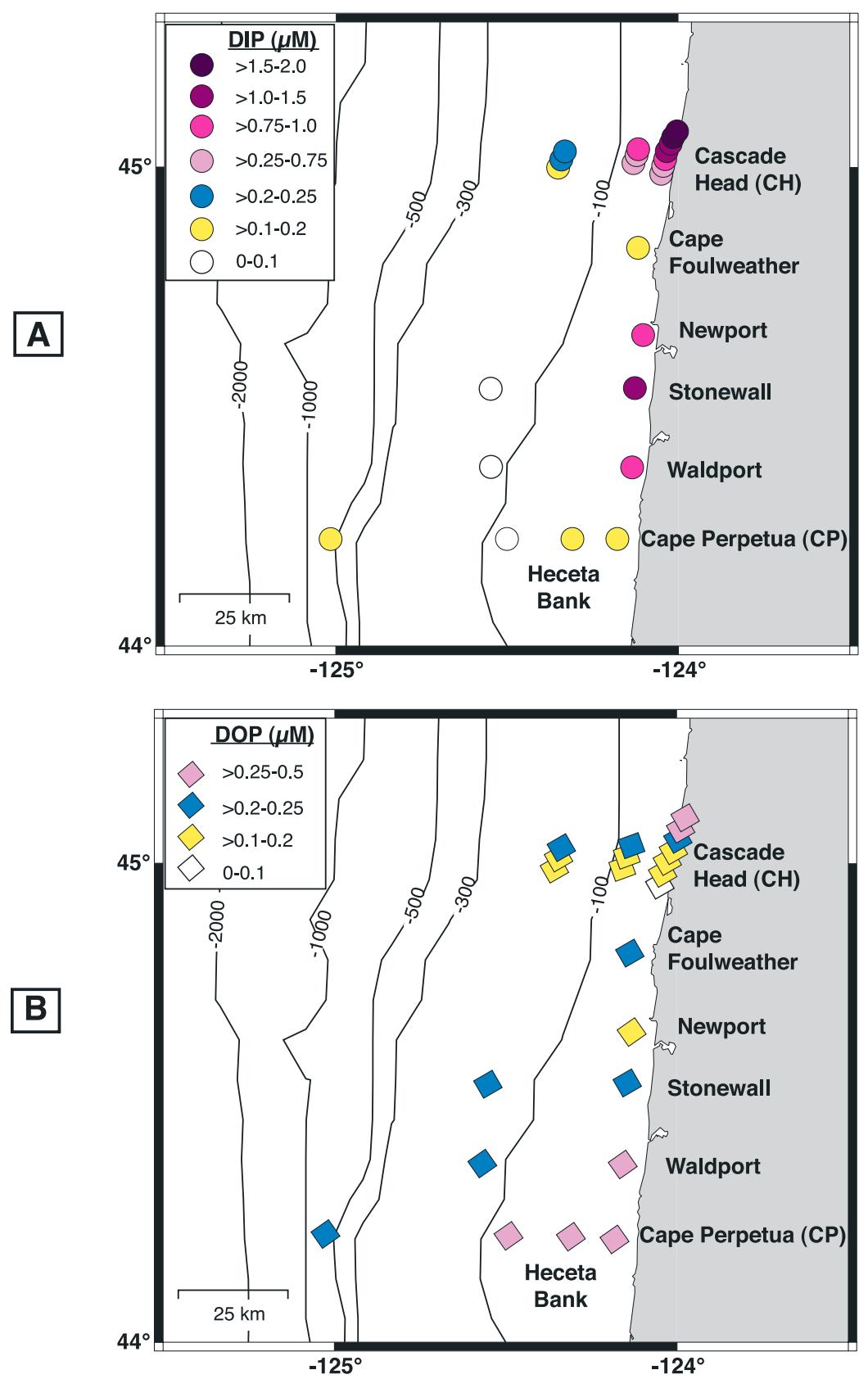

Figure 2. Spatial patterns of surface water DIP and DOP on the COAST-1 sampling grid: (a) DIP (range: $0.01-1.96 \mu \mathrm{M}$ ), and (b) DOP (range: $0.10-0.51 \mu \mathrm{M}$ ). Contours indicate water depth.

region (CP line) located on the bathymetrically more complex Heceta Bank (Figures 1 and 2, Table 1).

\section{Methods}

\subsection{Sample Collection}

[10] The ship dedicated to high vertical resolution profiling conducted nearshore-offshore transects (Figures 1 and 2), executing high-resolution continuous pumped water sampling with real-time dissolved inorganic nutrient analyses via autoanalyzer (see Hales et al. [2005] for a description of the pump-profiler). At designated stations along the transects (Table 1), discrete large volume depthprofile sampling was achieved by slowing the pump-profiler ascent, halting at predetermined sampling depths, and divert- ing the sample water stream into $20-\mathrm{L}$ carboys. These carboys were sampled for filtration and subsequent analysis of discrete samples for TDP, DIP, DOP, chlorophyll $a$, phytoplankton species composition, and enzymatic activity (this study), as well as numerous other biogeochemical parameters [Barth and Wheeler, 2005]. Repeat occupation of $\mathrm{CH}$ transect stations over a 7-day period was designed to reveal the degree of variability on short timescales and small spatial scales. Focus on the $\mathrm{CH}$ and $\mathrm{CP}$ lines was intended to afford a contrast between biogeochemical patterns on a narrow, topographically simple shelf versus a broad, topographically complex shelf within the same upwelling regime.

[11] After first gently inverting carboys to homogenize, water was collected from the carboy spigot into 1-L and 2-L polyethylene bottles, after first rinsing bottles 3 times with 
Table 1. COAST-1 (May 2001) Station Locations, Resampling Numbers, Sampling Dates, and Station Water Depths

\begin{tabular}{|c|c|c|c|c|c|}
\hline Station & $\begin{array}{l}\text { Resample } \\
\text { Number }^{\mathrm{a}}\end{array}$ & $\begin{array}{c}\text { Date } \\
\text { Collected }^{\mathrm{b}}\end{array}$ & ${ }^{\circ} \mathrm{N}$ Latitude & ${ }^{\circ} \mathrm{W}$ Longitude & $\begin{array}{c}\text { Water } \\
\text { Depth, m }\end{array}$ \\
\hline $\mathrm{CH}-1$ & 1 & $5 / 20 / 01$ & $45^{\circ} 0.5^{\prime}$ & $124^{\circ} 2.5^{\prime}$ & 34.4 \\
\hline $\mathrm{CH}-1$ & 2 & $5 / 21 / 01$ & $45^{\circ} 0.5^{\prime}$ & $124^{\circ} 2.5^{\prime}$ & 34.4 \\
\hline $\mathrm{CH}-1$ & 3 & $5 / 22 / 01$ & $45^{\circ} 0.5^{\prime}$ & $124^{\circ} 2.5^{\prime}$ & 34.4 \\
\hline $\mathrm{CH}-1$ & 4 & $5 / 24 / 01$ & $45^{\circ} 0.5^{\prime}$ & $124^{\circ} 2.5^{\prime}$ & 34.4 \\
\hline $\mathrm{CH}-1$ & 5 & $5 / 25 / 01$ & $45^{\circ} 0.5^{\prime}$ & $124^{\circ} 2.5^{\prime}$ & 34.4 \\
\hline $\mathrm{CH}-1$ & 6 & $5 / 25 / 01$ & $45^{\circ} 0.5^{\prime}$ & $124^{\circ} 2.5^{\prime}$ & 34.4 \\
\hline CH-1 & 7 & $5 / 26 / 01$ & $45^{\circ} 0.5^{\prime}$ & $124^{\circ} 2.5^{\prime}$ & 34.4 \\
\hline $\mathrm{CH}-3 / \mathrm{CH}-4$ & 1 & $5 / 22 / 01$ & $45^{\circ} 0.4^{\prime}$ & $124^{\circ} 7.8^{\prime}$ & 91.3 \\
\hline $\mathrm{CH}-3 / \mathrm{CH}-4$ & 2 & $5 / 25 / 01$ & $45^{\circ} 0.5^{\prime}$ & $124^{\circ} 7.8^{\prime}$ & 91.3 \\
\hline $\mathrm{CH}-3 / \mathrm{CH}-4$ & 3 & $5 / 27 / 01$ & $45^{\circ} 0.5^{\prime}$ & $124^{\circ} 7.8^{\prime}$ & 91.3 \\
\hline CH-6 & 1 & $5 / 21 / 01$ & $45^{\circ} 0.5^{\prime}$ & $124^{\circ} 20.0^{\prime}$ & 185.1 \\
\hline CH-6 & 2 & $5 / 24 / 01$ & $45^{\circ} 0.5^{\prime}$ & $124^{\circ} 20.0^{\prime}$ & 185.1 \\
\hline CH-6 & 3 & $5 / 27 / 01$ & $45^{\circ} 0.5^{\prime}$ & $124^{\circ} 20.0^{\prime}$ & 185.1 \\
\hline CP-2 & 1 & $5 / 28 / 01$ & $44^{\circ} 13.5^{\prime}$ & $124^{\circ} 10.7^{\prime}$ & 52.0 \\
\hline CP-3 & 1 & $5 / 29 / 01$ & $44^{\circ} 13.5^{\prime}$ & $124^{\circ} 18.5^{\prime}$ & 82.3 \\
\hline CP-5 & 1 & $5 / 30 / 01$ & $44^{\circ} 13.5^{\prime}$ & $124^{\circ} 30.0^{\prime}$ & 104.5 \\
\hline CP-11 & 1 & $5 / 29 / 01$ & $44^{\circ} 13.5^{\prime}$ & $125^{\circ} 0.9^{\prime}$ & 670.0 \\
\hline WY-1 & 1 & $5 / 31 / 01$ & $44^{\circ} 22.5^{\prime}$ & $124^{\circ} 8.0^{\prime}$ & 40.4 \\
\hline WY-2 & 1 & $5 / 31 / 01$ & $44^{\circ} 22.5^{\prime}$ & $124^{\circ} 32.8^{\prime}$ & 96.4 \\
\hline ST-1 & 1 & $6 / 01 / 01$ & $44^{\circ} 32.4^{\prime}$ & $124^{\circ} 7.6^{\prime}$ & 40.8 \\
\hline ST-2 & 1 & $6 / 01 / 01$ & $44^{\circ} 32.4^{\prime}$ & $124^{\circ} 32.9^{\prime}$ & 130.5 \\
\hline NHT-1 & 1 & $6 / 01 / 01$ & $44^{\circ} 39.1^{\prime}$ & $124^{\circ} 6.1^{\prime}$ & 31.9 \\
\hline CF-1 & 1 & $6 / 02 / 01$ & $44^{\circ} 50.0^{\prime}$ & $124^{\circ} 7.0^{\prime}$ & 57.3 \\
\hline
\end{tabular}

${ }^{a}$ Resample number equals 1 when stations were sampled only once. For stations that were sampled multiple times, the resample number denotes the number of times that the station was revisited; for example, Resample 2 refers to the second time a station was visited.

${ }^{\mathrm{b}}$ Dates are given as $\mathrm{m} / \mathrm{dd} / \mathrm{yy}$.

sample water. Capped bottles were stored refrigerated until filtered; filtration was commenced as soon as possible after collection, usually within $5 \mathrm{~min}$. When samples became back-logged owing to rapid-succession sampling, they were stored refrigerated for no more than 1 to 2 hours prior to filtration. All bottles and carboys were acid cleaned in $10 \%$ $\mathrm{HCl}$ prior to use.

\subsection{Sample Processing}

[12] After gently inverting the bottle to homogenize sample, splits of samples collected in 1-L bottles were filtered through $0.4-\mu \mathrm{m}$ and $0.2-\mu \mathrm{m}$ polypropylene filters for analysis of TDP and DIP. Samples were vacuum filtered using Nalgene ${ }^{B}$ polysulfone filtration apparatus at low pressure ( $\leq 5 \mathrm{psi})$ to prevent cell lysis [e.g., Bidigare, 1991; Karl et al., 1991; Matrai, 1991; Mopper and Furton, 1991]. Filtration apparatus were acid cleaned $(10 \% \mathrm{HCl})$ prior to initial use; between samples the upper reservoir was rinsed with unfiltered sample water, and the lower reservoir with the first $50 \mathrm{~mL}$ of filtrate to pass through the filter. Filtrates were collected in acid cleaned $(10 \% \mathrm{HCl})$ polypropylene bottles, acidified to $\mathrm{pH} 1$ with trace-metal clean $\mathrm{HCl}$, and stored refrigerated until analysis [Monaghan and Ruttenberg, 1999]. Polypropylene filters were soaked for $\geq 48$ hours in $10 \% \mathrm{HCl}$, removing and replacing acid at least 3 times during soaking, and then were soaked for $\geq 24$ hours in acidified methanol to remove organic wetting agents. After decanting the last rinse, $0.4-\mu \mathrm{m}$ filters were rinsed with Milli-Q water until acid had been completely removed, transferred to acid cleaned $(10 \% \mathrm{HCl})$ polypropylene mesh-lined petri dishes, air-dried and preweighed for later determination of suspended particulate concentrations. All $0.2-\mu \mathrm{m}$ filters were stored in $10 \% \mathrm{HCl}$ in acid-cleaned glass jars, and rinsed copiously with Milli-Q water just prior to use. Filtration blanks for dissolved $\mathrm{P}$ were below detection. After sample collection, filters were placed in acid-cleaned polycarbonate petri dishes lined with acid-cleaned polypropylene mesh, sealed in small zip-lock bags, and stored frozen $\left(-30^{\circ} \mathrm{C}\right)$, for future analysis of filtered particles.

[13] After gently inverting the bottle to homogenize sample, splits of samples collected in 2-L bottles were processed for phytoplankton enumeration (phytocounts), whole community cell-bound alkaline phosphatase activity (hereafter, whole community APA), and cell-specific APA with Enzyme Labeled Fluorescence $\left(E^{\circ} F^{\circledR}\right)$. Samples for enzyme analysis and phytocounts were taken from surface waters, and where present, from the depth of the subsurface chlorophyll a maximum. For phytocounts, $100 \mathrm{~mL}$ of unfiltered water was decanted into a volume-marked 125-mL polypropylene bottle, spiked with 1-mL gluteraldehyde, and stored in the dark at room temperature until analysis. For whole community APA, $500 \mathrm{~mL}$ of sample was filtered through a $0.2-\mu \mathrm{m}$ polycarbonate filter; filtration and filter storage were as described above for dissolved P. For ELF analyses, $1000 \mathrm{~mL}$ of sample was filtered through $0.8-\mu \mathrm{m}$ Supor ${ }^{\circledR}$ filters; filtrate was discarded and filter was immediately subjected to the ELF labeling procedure.

\subsection{Analytical Methods}

[14] Total dissolved phosphorus (TDP) was determined on $0.4-\mu \mathrm{m}$ and $0.2-\mu \mathrm{m}$ filtrates using the high-temperature ashing/hydrolysis method of Solórzano and Sharp [1980], as modified by Monaghan and Ruttenberg [1999]. Soluble reactive phosphorus (SRP) was determined by the standard phosphomolybdate blue method according to Koroleff [1983]. Dissolved Organic Phosphorus (DOP) is calculated as the difference between TDP and SRP.

[15] The term SRP describes the pool of dissolved phosphorus that is directly reactive toward complexation with molybdate, without any chemical pretreatment. This pool is dominated by orthophosphate, and thus has also been referred to as the dissolved inorganic phosphorus (DIP) pool. SRP can overestimate DIP in cases where easily hydrolyzable DOP compounds make up a significant fraction of the dissolved $\mathrm{P}$ pool, as there is potential for reactive DOP to hydrolyze under the acidic conditions of the phosphomolybdate reaction [Rigler, 1968; Hudson et al., 2000]. In contrast, SRP can underestimate the DIP pool if polyphosphates are present at significant concentrations, as these polymers of orthophosphate are not hydrolyzable on the timescale of the phosphomolybdate reaction [Monaghan and Ruttenberg, 1999; Solórzano and Strickland, 1968].

[16] Evaluation of extent of hydrolysis of a suite of standard DOP compounds and DOP from coastal northern California waters, under phosphomolybdate reaction conditions, indicated that $<2 \%$ of all but one DOP standard is hydrolyzed (the high-energy compound phosphocreatine hydrolyzed $4.6 \%$ ), and no apparent hydrolysis of the natural seawater sample occurred [Monaghan and Ruttenberg, 1999]. Extent of hydrolysis during acidified ( $\mathrm{pH} 1) /$ refrigerated storage showed similar results, with no detectable DOP hydrolysis in the natural seawater sample after 84 days, and slightly higher $(<5 \%)$ hydrolysis of most standard DOP compounds after 13-16 days. Again, exceptions were the high energy compound phosphocreatine ( $86 \%$ hydrolyzed), 
expected to represent at most a minute fraction of the natural DOP pool, if present at all, and the triphosphate nucleotide GTP (9.3\% hydrolyzed); note that ATP hydrolyzed $<5 \%$ [Monaghan and Ruttenberg, 1999]. An advantage to storing samples under acidified conditions prior to analysis is that any polyphosphates will hydrolyze, removing this potential DIP under-recovery artifact. For simplicity, we will refer to SRP as DIP in sections 4 and 5, recognizing the possibility that SRP may be an approximation of "true" DIP. Importantly, the results of Monaghan and Ruttenberg [1999] suggest that this may be a robust approximation for coastal marine waters.

[17] Analysis of whole community APA was performed on cell concentrates obtained by filtration of seawater samples through $0.2-\mu \mathrm{m}$ polycarbonate filters. Frozen filters were incubated at room temperature in 2-mL sterile, phosphate-free artificial seawater (ASW) [Lyman and Fleming, 1940] on a shaker table (200 rpm) for $10 \mathrm{~min}$. The fluorogenic phosphatase substrate 6,8-difluoro-4-methylumbelliferyl phosphate (DiFMUP, Molecular Probes ${ }^{\mathbb{B}}$ ) was added to each sample at a final concentration of $10 \mu \mathrm{M}$. Initial kinetic experiments in this system indicated that $10 \mu \mathrm{M}$ is saturating for assays of maximal activity (data not shown). After incubating with DiFMUP, splits of samples were transferred to wells in a 48 -well Co-Star ${ }^{\circledR}$ sample plate. Hydrolysis of DiFMUP to the fluorescent product, 6, 8-difluoro-7-hydroxy-4-methylcoumarin (DiFMU), was measured immediately on a temperature controlled $\left(25^{\circ} \mathrm{C}\right)$ CytoFluor multiwell plate reader (Perseptive Biosystems $\left.{ }^{6}\right)$, and then at time intervals adjusted such that the activity in the sample stayed in the linear range of the assay (at least four measurements within 4 hours or less). When present, APase will cleave phosphate from the DiFMUP substrate, releasing orthophosphate and the fluorescent DiFMU compound in direct proportion. Samples were rotated gently on a shaker table in between fluorescence measurements. A standard curve from $0 \mu \mathrm{M}$ to $4.8 \mu \mathrm{M}$ DiFMU (Molecular Probes ${ }^{\circledR}$ ) in ASW was generated and used to calculate the rate of DOP hydrolysis. All hydrolyzed substrate concentrations measured in sample assays fell within this standard range.

[18] Cell-specific APA was performed according to the protocol of Dyhrman and Palenik [1999]. Briefly, 1 L of seawater was filtered through a Gelman Supor ${ }^{B}$ filter (nominal pore size $0.8 \mu \mathrm{m}$ ), taking care not to allow the cell concentrate to dry out. Concentrated cells were immediately resuspended into $1 \mathrm{~mL}$ of $70 \%$ ethanol, placed into an epitube, and stored at $4{ }^{\circ} \mathrm{C}$ prior to the ELF substrate incubation. Samples were processed within 2 weeks of sample collection. Briefly, the ethanol was removed via centrifugation and the resulting cell pellet was resuspended in sterile, low phosphate seawater with 5\% ELF-97 phosphatase substrate (Molecular Probes ${ }^{B}$ ) and incubated for 1 hour in the dark. After this incubation the cells were washed twice and resuspended in $50 \mu \mathrm{L}$ of sterile, low phosphate seawater. These cell suspensions were stored at $4^{\circ} \mathrm{C}$ prior to microscopic examination. Cells from the ELF-labeling process were examined with a Zeiss epifluorescence microscope using a DAPI (4', 6'-diamidino-2-phenyl-indole) long pass filter set (ELF has a maximum emission at $520 \mathrm{~nm}$ when excited at $350 \mathrm{~nm})$. All cells were counted using brightfield or DIC optics and then scored for positive or negative
ELF-labeling based on the presence or absence of the fluorescent precipitate visible with the DAPI filter set. Percent ELF labeling for a given genus is reported as the fraction of fluorescently labeled cells relative to the total number of cells counted within that genus. Phytoplankton cell counts on gluteraldehyde-preserved grab samples were performed by Phycotech, Inc.

[19] Chlorophyll $a$ ( $\operatorname{chl} a$ ) was measured on whole water samples collected onto GF/F filters using a standard 95\% methanol extraction. The details of these chl $a$ assays are described elsewhere [Wetz and Wheeler, 2005].

\section{Results}

[20] Sampling station locations for this study are summarized in Table 1. The nearshore, midshelf, and offshore stations along the northernmost $\mathrm{CH}$ line (stations $\mathrm{CH}-1$, $\mathrm{CH}-3 / 4$, and $\mathrm{CH}-6$, water depths from 34.4 to $185.1 \mathrm{~m}$ ) were resampled daily within a span of a week, with the aim of documenting daily variability in biogeochemistry along this cross-shelf transect. A second cross-shelf transect was occupied in the southernmost sampling grid (CP line), along which an array of four stations (water depths from 52 to $670 \mathrm{~m}$ ) were each occupied once, the entire transect being sampled within a time span of 3 days. Six additional stations arrayed between the $\mathrm{CH}$ and $\mathrm{CP}$ lines were each sampled once within a 3-day period, immediately following completion of CP-line sampling (Table 1, Figures $2 \mathrm{a}$ and $2 \mathrm{~b}$ ). All sampling was completed within 14 days, between 20 May 2001 and 2 June 2001.

[21] Sample temperature, salinity, chl $a$, and dissolved phosphorus data are summarized in Table 2. Temperature and salinity data are from the shipboard system. Chl $a$ data are from Wetz and Wheeler [2005].

\subsection{Concentration Ranges, Precision, and Accuracy of Dissolved Phosphorus Data}

[22] Total dissolved phosphorus (TDP) concentrations in $0.4-\mu \mathrm{m}$ filtrates ranged from 0.24 to $2.78 \mu \mathrm{M}$, with a mean concentration of $1.79 \pm 0.79 \mu \mathrm{M}$. The TDP range for $0.2-\mu \mathrm{m}$ filtrates was $0.21-2.98 \mu \mathrm{M}$, with a mean concentration of $1.79 \pm 0.79 \mu \mathrm{M}$ (Table 2; definition of errors is provided in table footnotes). Precision of TDP analyses averaged $\pm 0.02 \mu \mathrm{M}$. No samples fell below the detection limit for TDP (3 times precision, or $0.06 \mu \mathrm{M}$ ). Dissolved inorganic phosphorus (DIP) concentrations in $0.4-\mu \mathrm{m}$ filtrates ranged from 0.01 to $2.84 \mu \mathrm{M}$, with a mean concentration of $1.62 \pm$ $0.83 \mu \mathrm{M}$. The DIP range for $0.2-\mu \mathrm{m}$ filtrates was $0.01-$ $2.85 \mu \mathrm{M}$, with a mean concentration of $1.62 \pm 0.83 \mu \mathrm{M}$ (Table 2). Precision of DIP analyses averaged $\pm 0.01 \mu \mathrm{M}$. Two samples (CP-5 $(5 \mathrm{~m})$ and ST-2 $(5 \mathrm{~m}))$ fell below the calculated detection limit for DIP (3 times precision, or $0.03 \mu \mathrm{M}$ ). Dissolved organic phosphorus (DOP) concentrations in $0.4-\mu \mathrm{m}$ filtrates ranged from undetectable to $0.43 \mu \mathrm{M}$, with a mean concentration of $0.17 \pm 0.09 \mu \mathrm{M}$. The DOP range for $0.2-\mu \mathrm{m}$ filtrates was from undetectable to $0.51 \mu \mathrm{M}$, with a mean concentration of $0.16 \pm 0.12 \mu \mathrm{M}$. Precision of DOP analyses, as calculated by propagating the error from TDP and DIP measurements (see Table 2), averaged $\pm 0.02 \mu \mathrm{M}$. Because the concentrations in paired 0.4 - and $0.2-\mu \mathrm{m}$ filtrates of all three P pools are essentially indistinguishable (Table 2), for simplicity we will limit our 


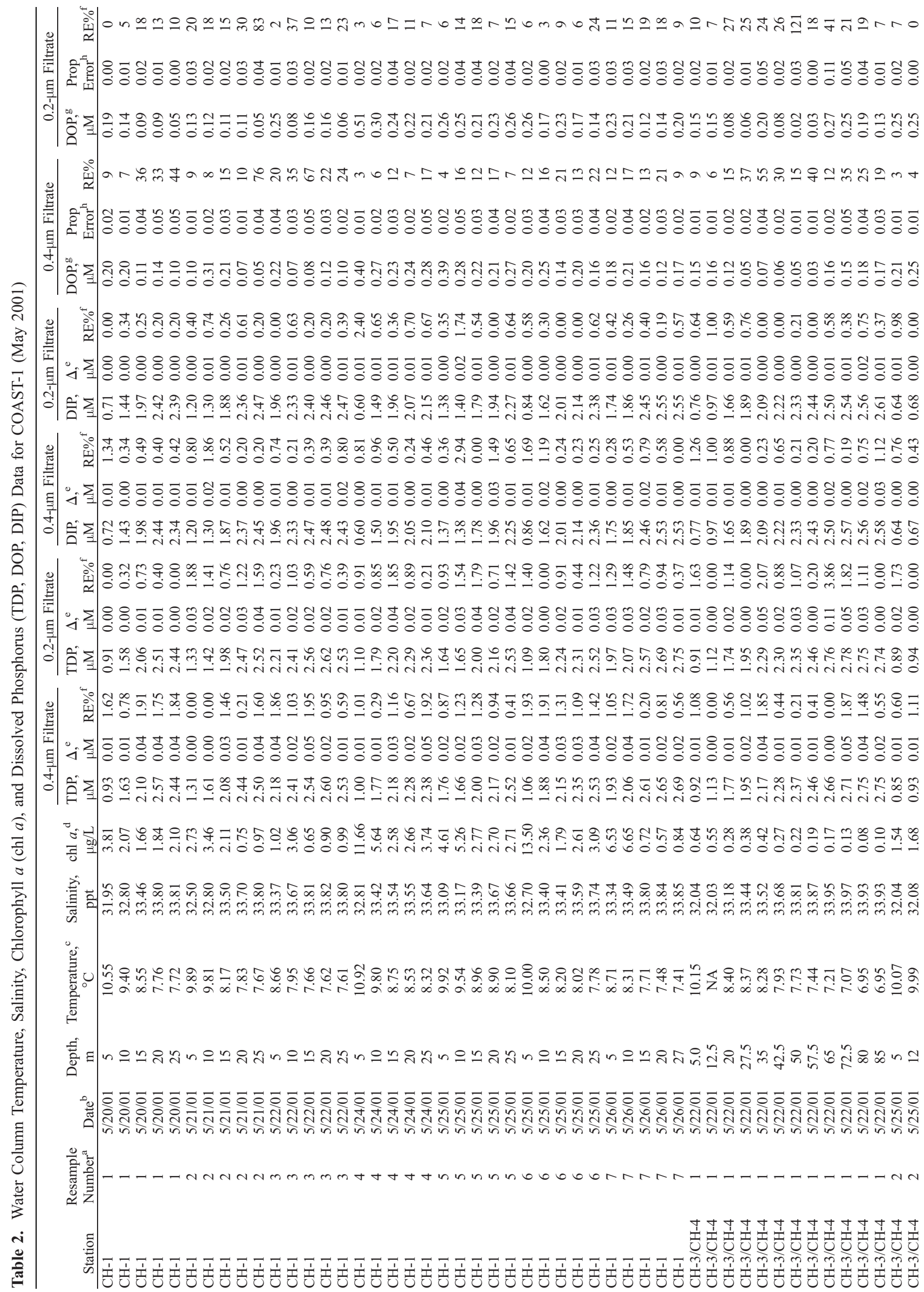




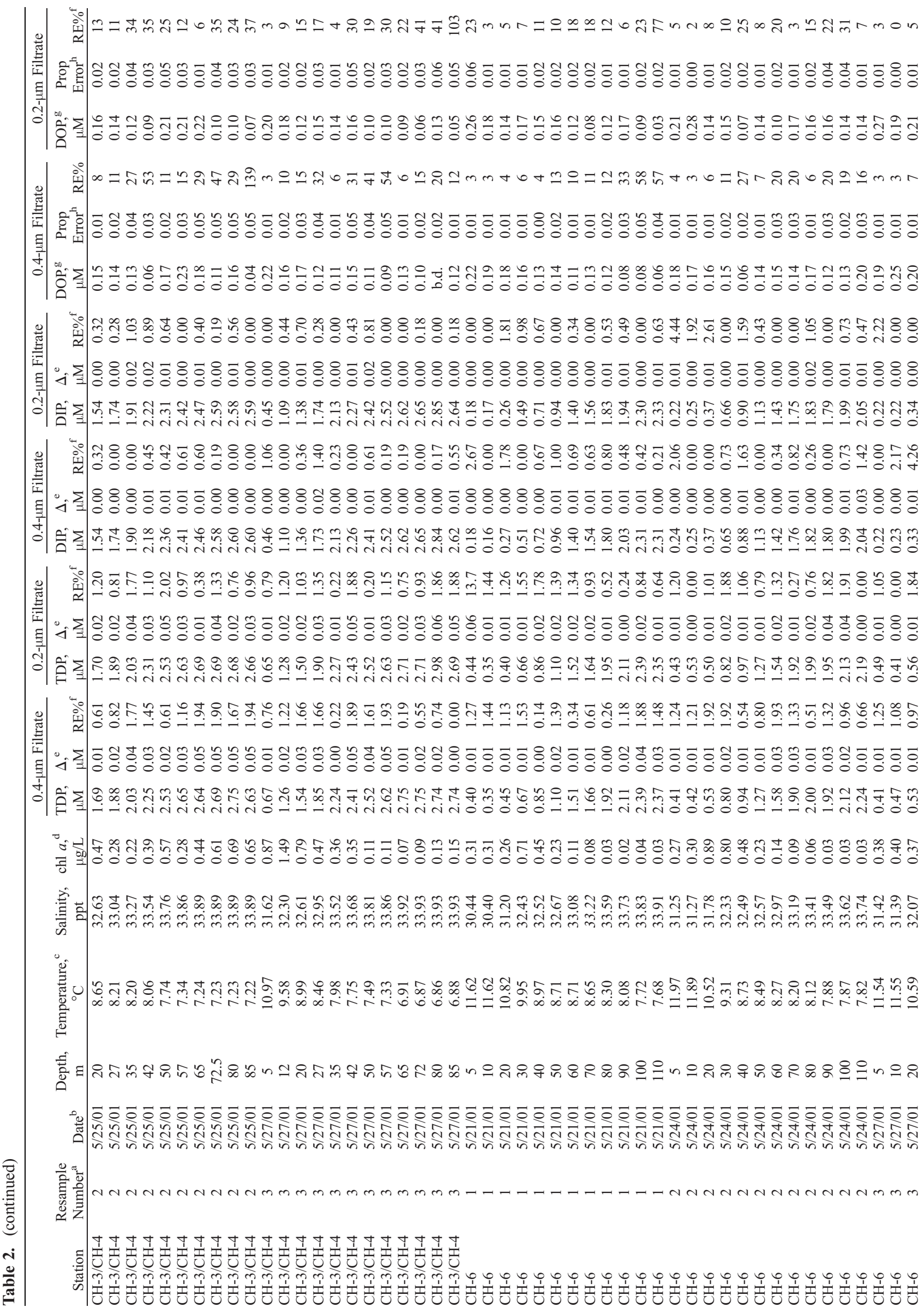




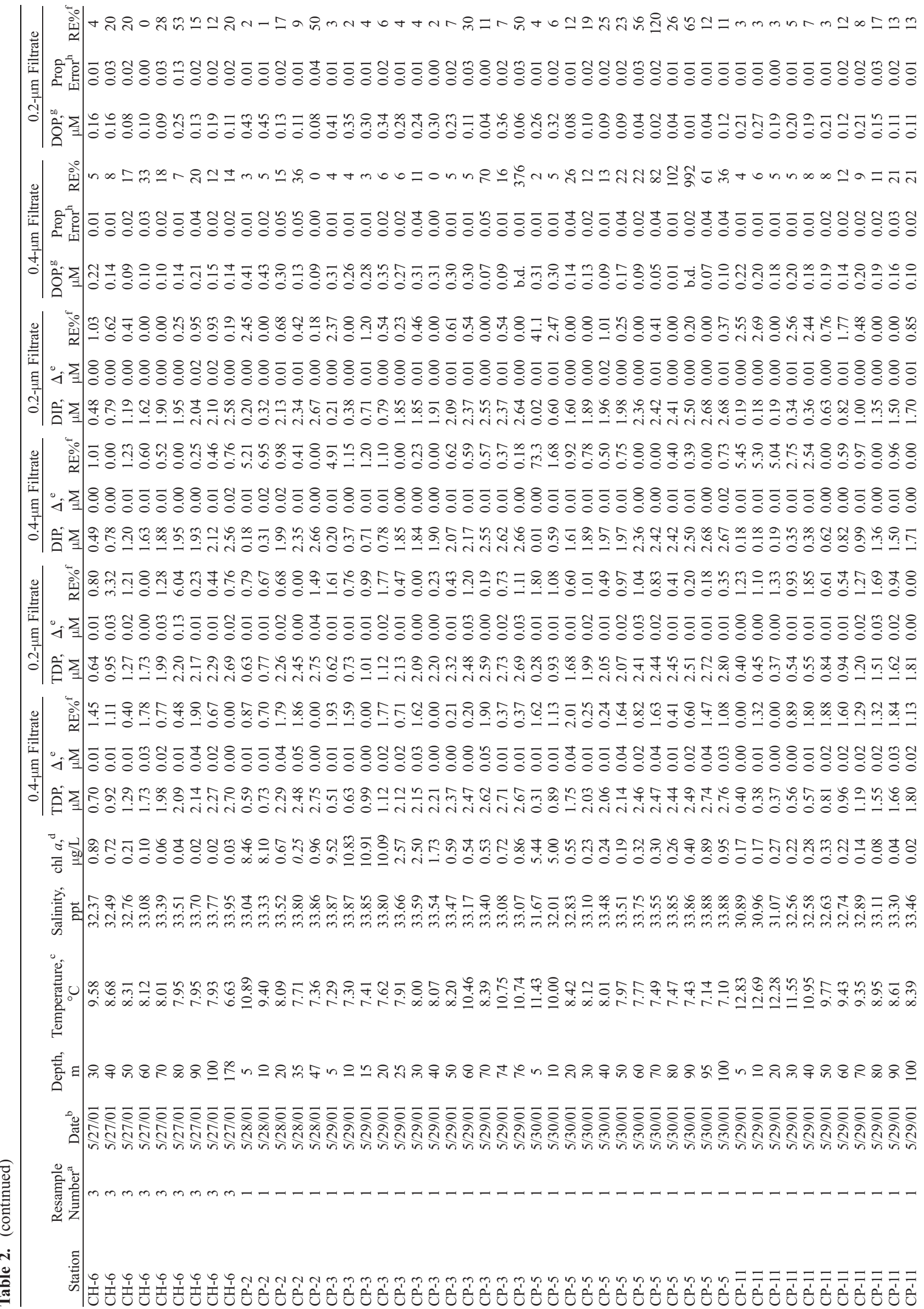




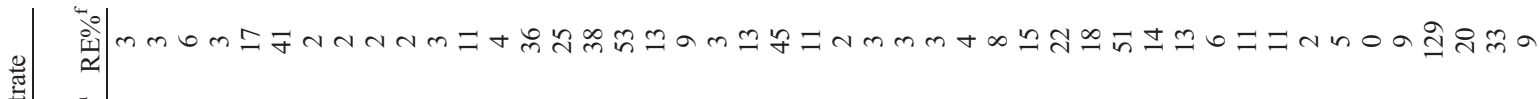

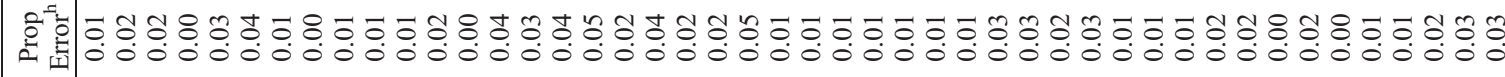

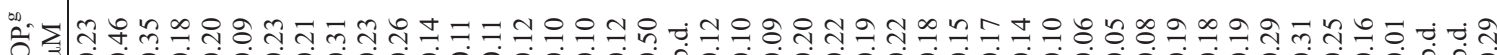

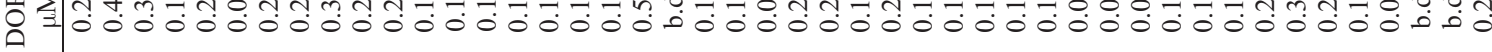

递の 苛

行 荇.

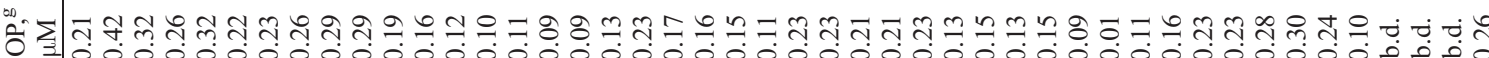

แั้ำน

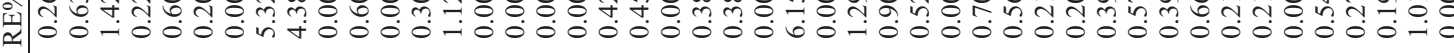

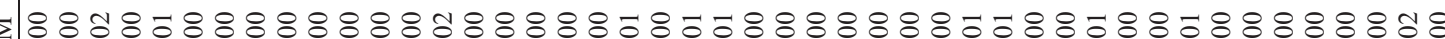

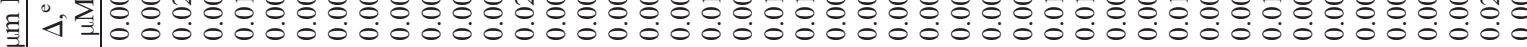
กิ|

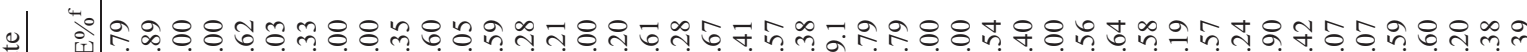

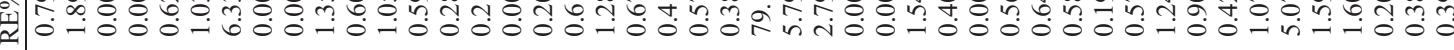

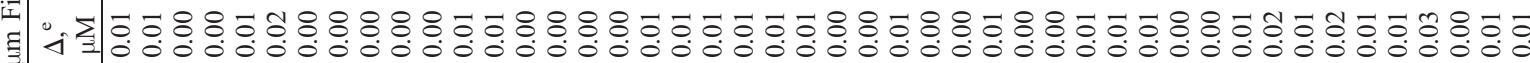

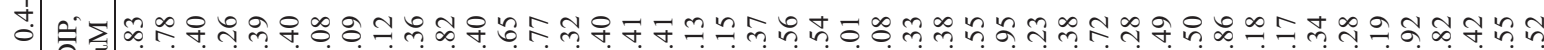

แำ

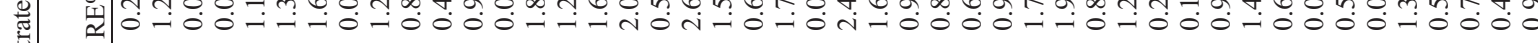

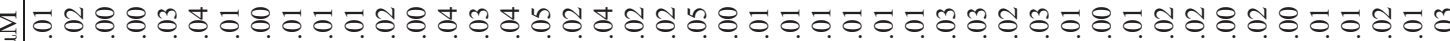

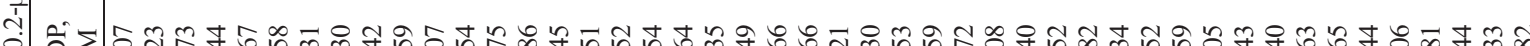
a

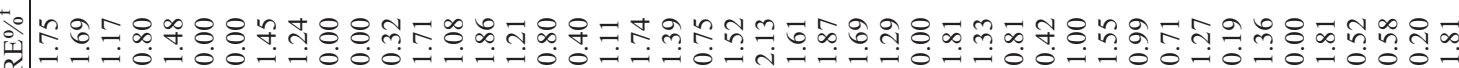

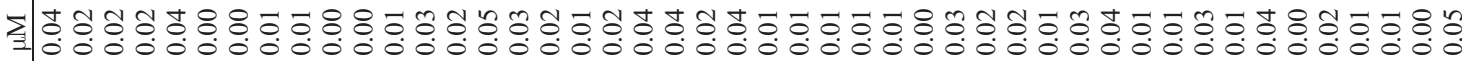

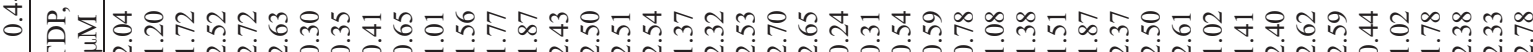

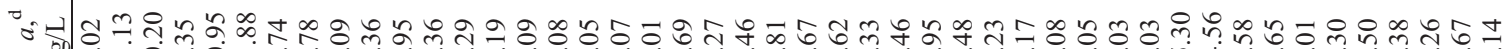
긍

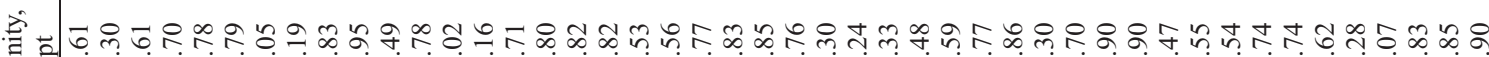
ज्ञ

売 离 $\stackrel{0}{\oplus}$

葛

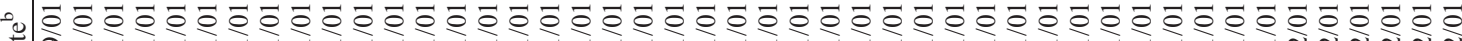

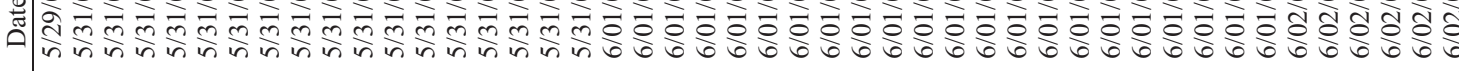

焉 离

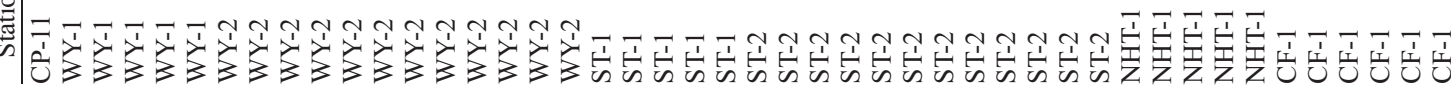



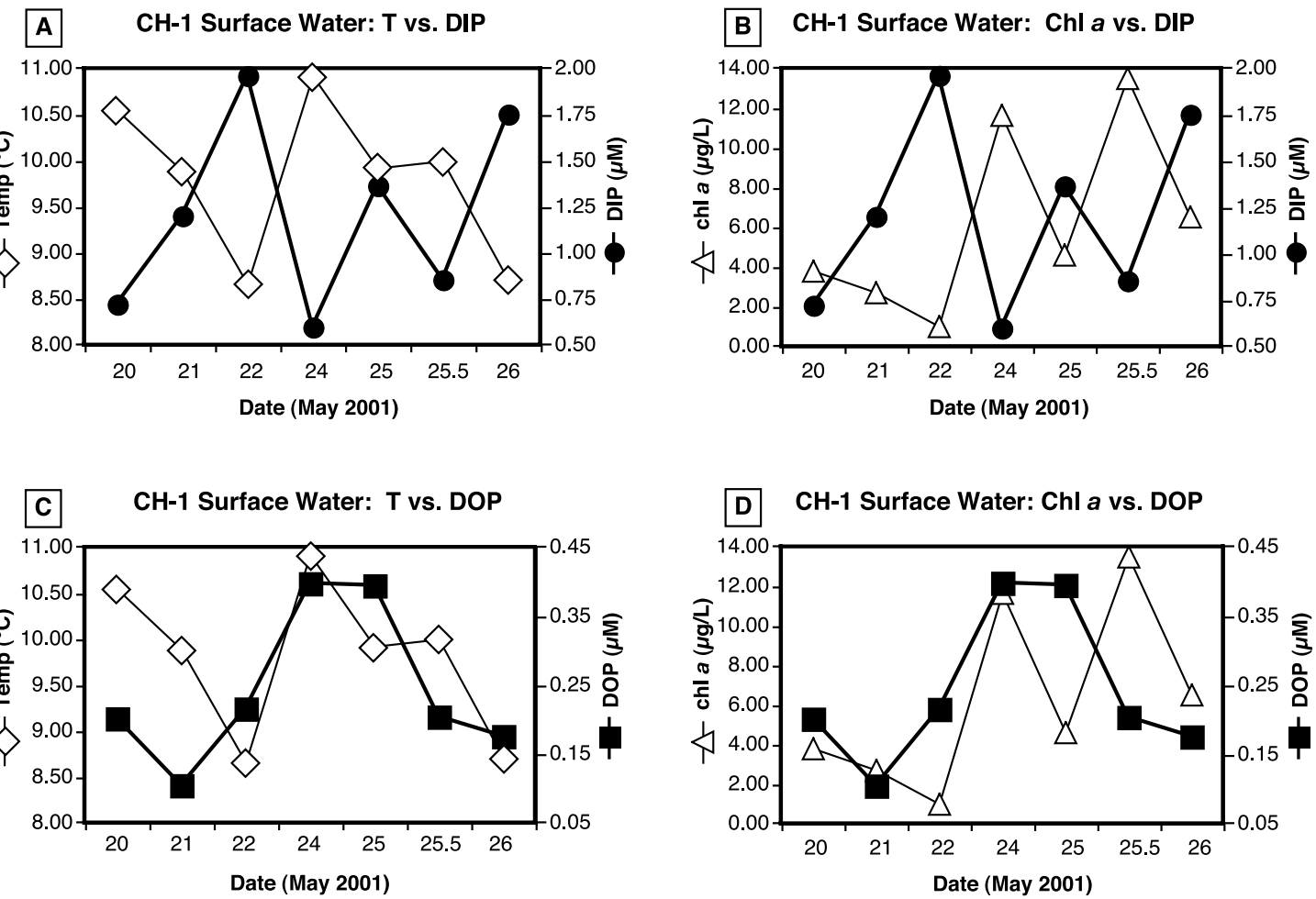

Figure 3. COAST-1 surface water data from nearshore station $\mathrm{CH}-1$, the most frequently resampled station along the $\mathrm{CH}$ line. Two upwelling-relaxation events were encountered over 7 days, from $20-$ 26 May, as indicated by the fluctuating temperature trends. DIP varies inversely with (a) temperature and (b) chlorophyll $a(\mathrm{chl} a$ ) in response to upwelling. In contrast, DOP tracks (c) temperature and (d) chl $a$. Chlorophyll $a$ data are from Wetz and Wheeler [2005].

presentation of field data to the $0.4-\mu \mathrm{m}$ data; results and interpretations based on $0.2-\mu \mathrm{m}$ filtrates would be identical.

\subsection{Spatial Variability of Dissolved $P$ in Surface Waters}

[23] Surface water DIP and DOP concentrations vary substantially over the sampling grid (Figures $2 \mathrm{a}$ and $2 \mathrm{~b}$ ). The highest DIP levels are found at nearshore stations, varying between $0.18-0.20$ at CP-2, CP-3, and Cape Foulweather ( $<83 \mathrm{~m}$ water depth, and within $13 \mathrm{~km}$ of shore), to $1.96 \mu \mathrm{M}$ at $\mathrm{CH}-1(<35 \mathrm{~m}$ water depth, and within $5 \mathrm{~km}$ of shore), the highest surface water concentrations observed during the study (Figure 2a). There is an apparent trend from low DIP in the southern portion of the field area, over Heceta Bank, to higher concentrations in the northern portion, along the Cascade Head line. A clear trend of diminishing DIP levels is apparent in progressively more offshore, deeper water stations, with lowest DIP levels found in stations offshore of Heceta Bank $(0.01-0.08 \mu \mathrm{M})$, along the Stonewall, Waldport, and Cape Perpetua lines.
[24] A much smaller range of variability is observed in DOP concentrations relative to DIP, and the pattern of DOP variability is distinct from that of DIP (Figure 2b). As was the case for DIP, the highest DOP levels are found at the more nearshore stations, but the gradient in DOP with increasing distance offshore is much less pronounced than that observed for DIP. Offshore stations do not reach the low levels observed for DIP; minimum surface water DOP concentrations observed offshore are in the $0.2-0.25 \mu \mathrm{M}$ range. Higher DOP levels are consistently observed overall in the southernmost portion of the grid, in the vicinity of Heceta Bank, while the lowest DOP levels are observed along the northernmost $\mathrm{CH}$ transect, which is the opposite of the DIP trend.

\subsection{Temporal Variability of Dissolved $P$} in Surface Waters

[25] During the 7-day period from 20 May to 26 May 2001, the inshore station along the $\mathrm{CH}$ line was sampled 7 times (Table 1). Two upwelling and two relaxation events occurred during this timeframe, as evidenced by the pattern

\footnotetext{
Notes to Table 2:

${ }^{a}$ Resample number equals 1 when stations were sampled only once. For stations that were sampled multiple times, the resample number denotes the number of times that the station was revisited; for example, Resample 2 refers to the second time a station was visited.

${ }^{b}$ Dates are given as $\mathrm{m} / \mathrm{dd} / \mathrm{yy}$.

${ }^{\mathrm{c}}$ Abbreviation NA denotes data not available.

${ }^{\mathrm{d}}$ Chlorophyll $a$ data are from Wetz and Wheeler [2005].

${ }^{\mathrm{e}} \Delta$ denotes difference between duplicate dissolved $\mathrm{P}$ concentration measurements.

${ }^{\mathrm{f}} \mathrm{RE} \%$ denotes relative error: $(\Delta /$ mean dissolved $\mathrm{P}$ concentration $) \times 100$, where the mean dissolved $\mathrm{P}$ concentration is taken over duplicate measurements. ${ }^{\mathrm{g}}$ Abbreviation b.d. denotes below detection.

${ }^{h}$ Prop Error, propagated error calculated for DOP concentrations: square root $\left\{\left(\Delta_{\mathrm{TDP}}\right)^{2}+\left(\Delta_{\mathrm{DIP}}\right)^{2}\right\}$, where $\Delta_{\mathrm{TDP}}$ and $\Delta_{\mathrm{SRP}}$ are calculated from duplicate measurements of TDP and DIP, respectively.
} 
DOP $(\mu \mathrm{M})$
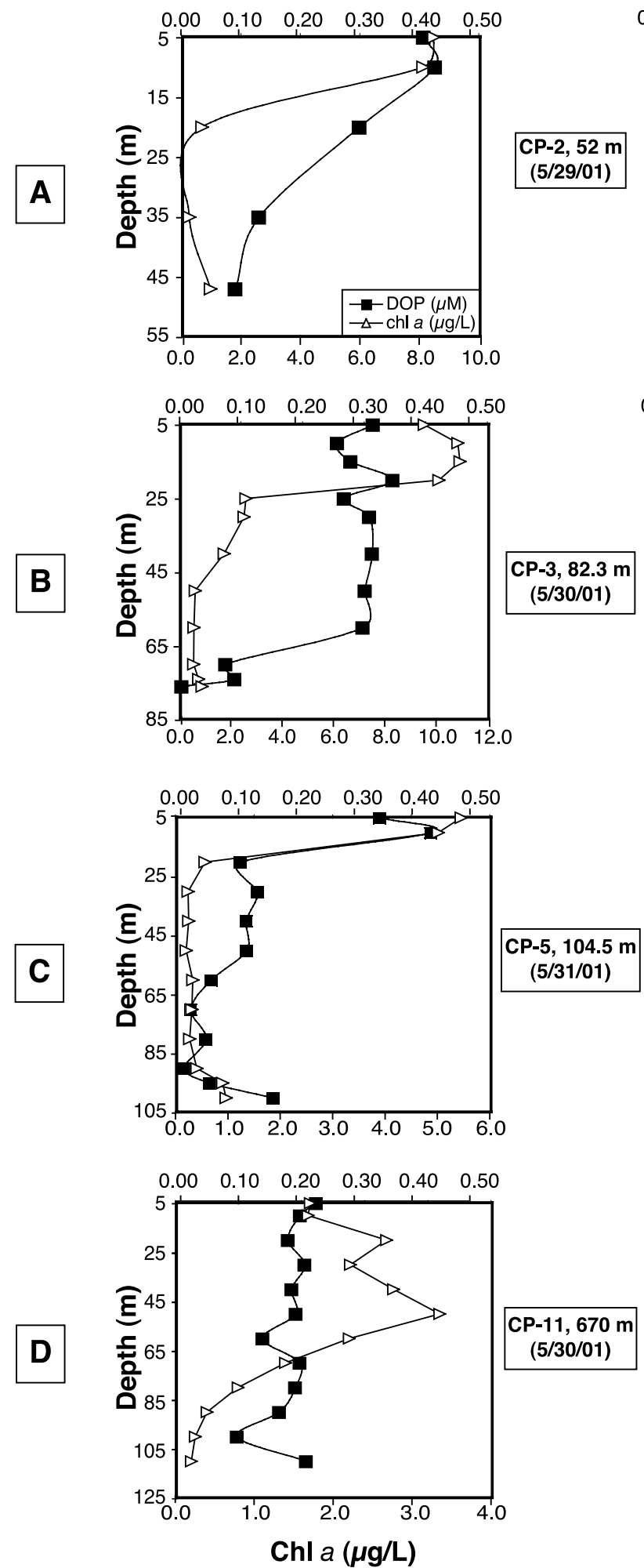

\section{DIP $(\mu \mathrm{M})$}
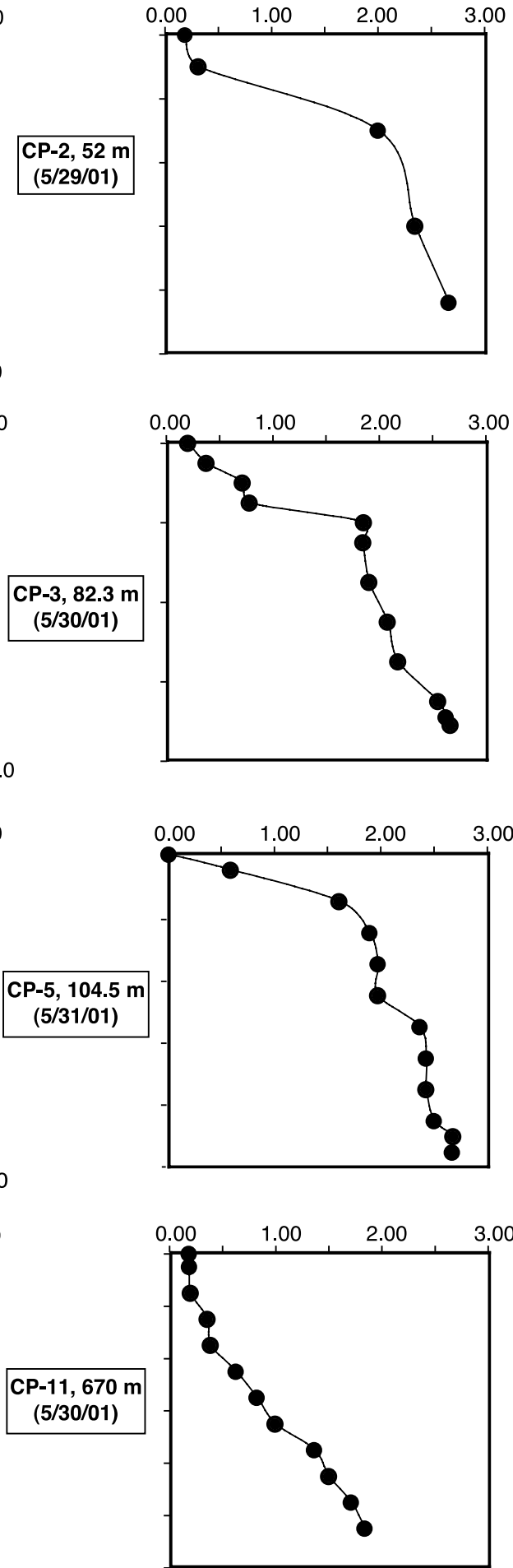

Figure 4. Spatial variability in DOP and DIP depth profiles: CP transect. Depth profiles of DOP (squares) and DIP (circles) along the CP-transect line, from (a) the shallowest, most nearshore station CP2 and progressively deeper stations (b) CP-3, (c) CP-5, and (d) CP-11. Sampling date and water depth are given in the legend for each panel. Note the difference in concentration scales for DOP and DIP plots. Chlorophyll $a$ (chl $a$ : triangles) trends generally parallel DOP trends, particularly for the three shallowest stations. Chl $a$ data are from Wetz and Wheeler [2005]. 


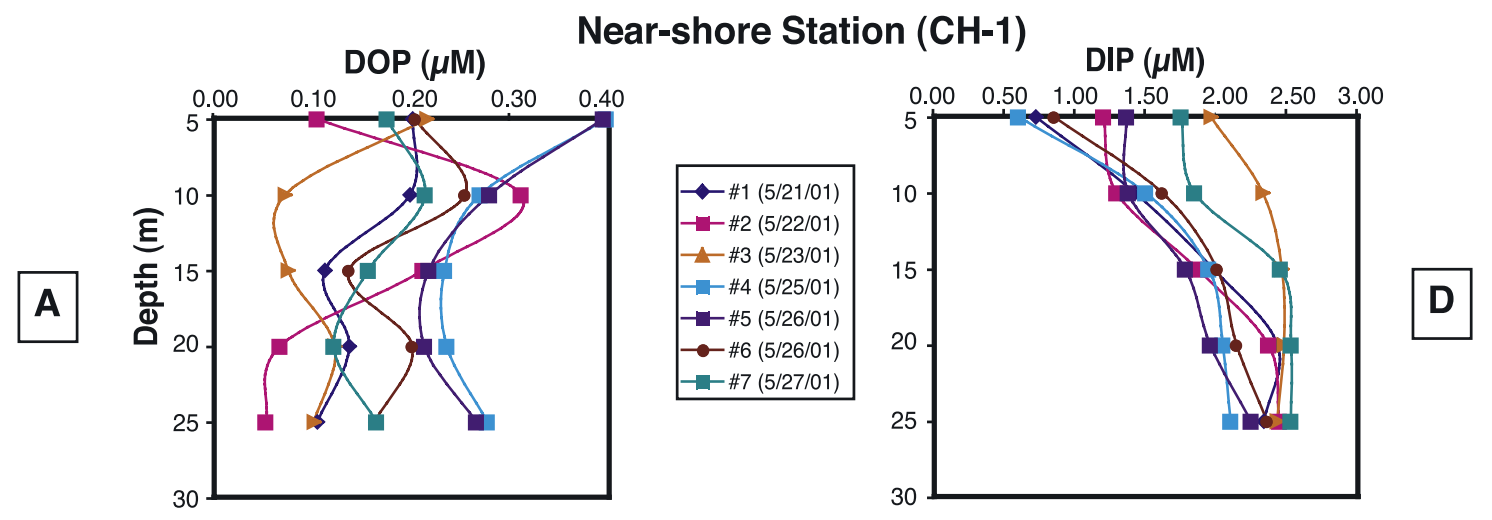

Mid-shelf Station (CH-3/4)

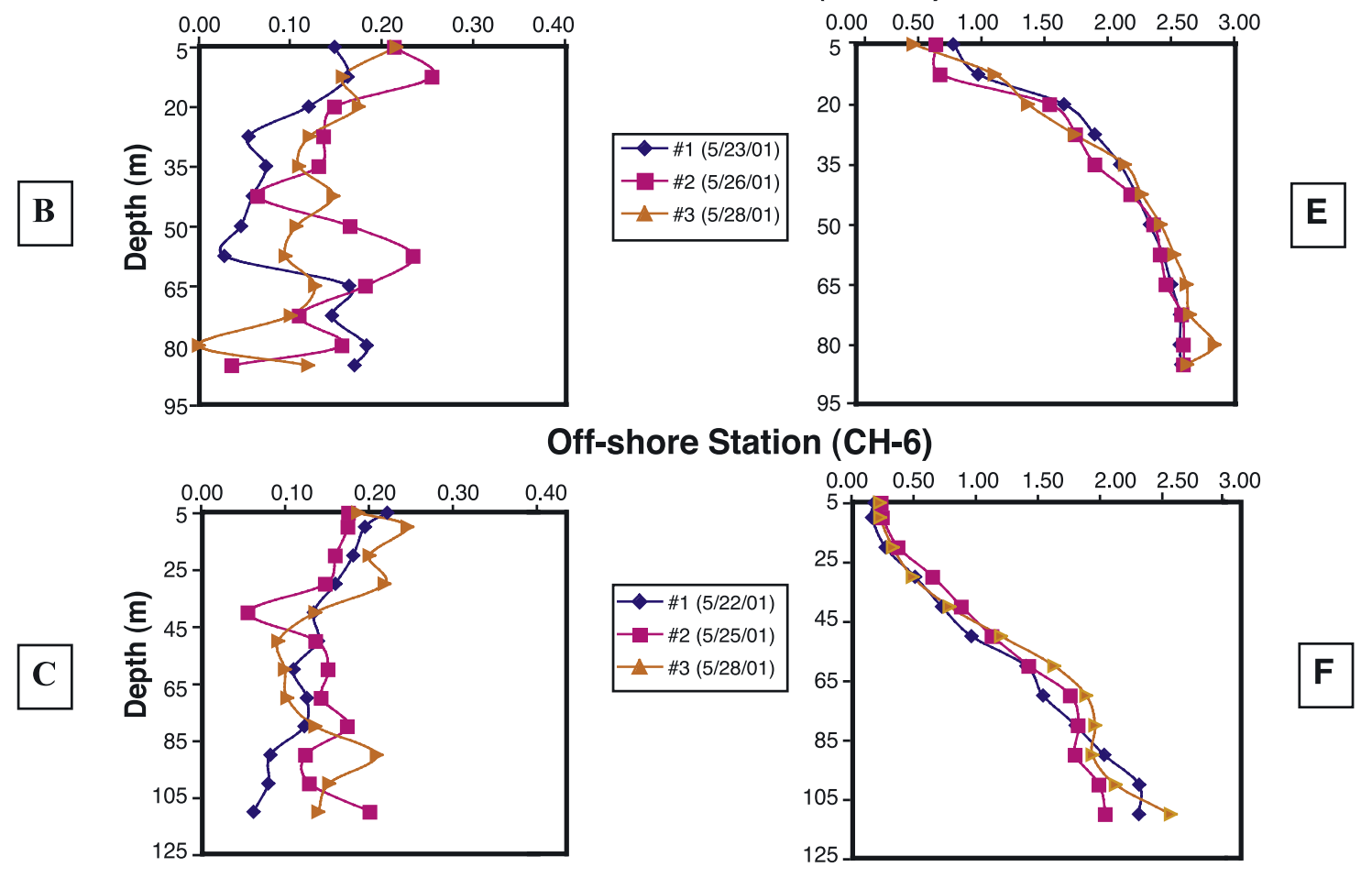

Figure 5. Spatial and temporal variability in DOP and DIP depth profiles: $\mathrm{CH}$ transect. Depth profiles of ( $a, b, c)$ DOP and (d, e, f) DIP along the CH-transect line, from the shallowest, most nearshore station $\mathrm{CH}-1$ (Figures $5 \mathrm{a}$ and $5 \mathrm{~d}$ ), and progressively deeper stations $\mathrm{CH}-3 / 4$ (Figures $5 \mathrm{~b}$ and $5 \mathrm{e}$ ), and $\mathrm{CH}-6$ (Figures 5c and 5f). Legend gives sampling dates for each panel. Note the difference in concentration scales for DOP and DIP plots.

of surface water temperature variability (Figures $3 \mathrm{a}$ and $3 \mathrm{c}$ ), with warmer temperatures observed during relaxation events and colder temperatures reflecting the presence of upwelled deep waters. Chl $a$ concentrations track temperature, with minima occurring in upwelled colder waters, and maximum concentrations occurring during relaxation events, when surface waters are characterized by warmer temperatures. DIP and TDP (TDP data not shown) are inversely correlated with temperature and chl $a$ (Figures $3 \mathrm{a}$ and $3 \mathrm{~b}$ ), while DOP tracks temperature and chl $a$ (Figures $3 \mathrm{c}$ and $3 \mathrm{~d}$ ).

\subsection{Depth Distributions of Dissolved P: Spatial and Temporal Variability}

[26] DIP and DOP depth profiles for stations from the CP line, in general, display mirror-image concentration profiles: DOP concentrations are highest in surface waters and diminish with depth below the surface, while DIP concentrations are lowest in surface waters and increase with depth (Figure 4: note the difference in concentration scales for DIP and DOP). The near surface concentration maxima in DOP correspond to near-surface chl $a$ concentration maxima, particularly in the shallowest three stations (CP-2, -3, and -5 : Figures $4 \mathrm{a}, 4 \mathrm{~b}$, and $4 \mathrm{c})$; this correspondence breaks down at the deepest station (CP-11: Figure 4d) where chl $a$ concentrations are substantially lower than at the nearshore and midshelf stations. Surface water DIP and DOP levels also diminish with distance offshore, and surface to depth gradients are less steep in offshore stations relative to nearshore stations. The shallowest station (CP-2, Figure 4a) displays the most regular depth variations, and the clearest mirror-image relationship between DIP and DOP. TDP depth profiles (not shown) are nearly identical to DIP profiles. 

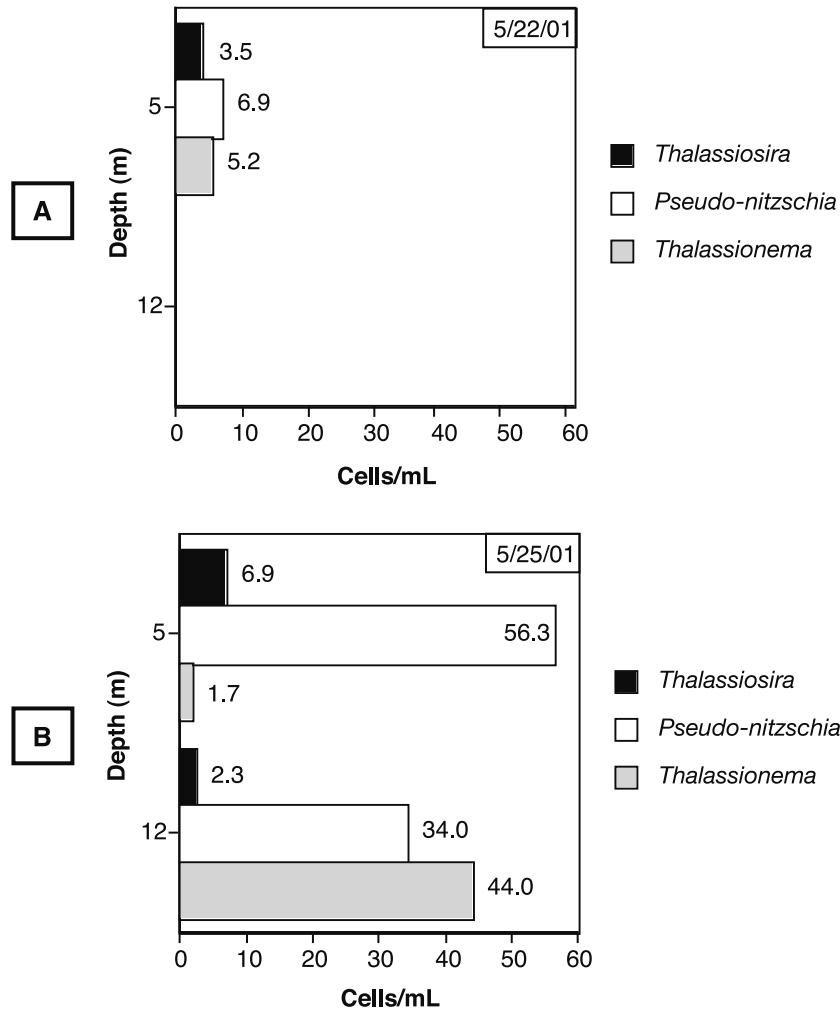

Figure 6. Spatial and temporal variability in diatom genus distribution: station $\mathrm{CH}-3 / 4$. Three common diatom genera observed during COAST-1, Thalassiosira, Pseudonitzschia, and Thalassionema are shown on two sampling dates: (a) 22 May $2001(5 \mathrm{~m})$, and (b) 25 May $2001(5 \mathrm{~m}$ and $12 \mathrm{~m}$ ). There was no subsurface chl $a$ maximum on 22 May, hence the absence of data for the 12-m depth. In contrast, a well-developed chl $a$ maximum was present on 25 May (Table 2), and thus samples from both surface waters and the depth of the chl $a$ maximum were assayed.

[27] Multiple resampling of DIP and DOP depth profiles for stations along the $\mathrm{CH}$ line (Table 1) affords insight into temporal as well as spatial variability (Figure 5). The same general features noted for the $\mathrm{CP}$ transect (Figure 4) are present along the $\mathrm{CH}$ line: (1) DIP concentrations are lowest in surface waters and increase with depth, while (2) DOP gradients trend in the opposite direction, with highest concentrations at the surface; (3) surface water DIP and DOP concentrations diminish from higher levels at nearshore stations to lower levels at offshore stations; and (4) gradients in DIP an DOP are steepest in nearshore stations, and become progressively less steep with distance offshore. While the nearshore station (CH-1) displays substantial temporal variability in both DIP and DOP depth profiles (Figures $5 \mathrm{a}$ and $5 \mathrm{~d}$ ), the midshelf (Figures $5 \mathrm{~b}$ and $5 \mathrm{e}$ ) and offshore (Figures $5 \mathrm{c}$ and $5 \mathrm{f}$ ) stations display insignificant temporal variability in DIP; DOP, while more variable than DIP, still displays less temporal variability than is observed at the nearshore station. TDP depth profiles (not shown) are nearly identical to DIP profiles.

4.5. Spatial Variability in Phytoplankton Community Composition and Alkaline Phosphatase Activity (APA)

[28] As an example of the spatial variability encountered in phytoplankton community composition, the distribution of three common diatom genera (Thalassiosira, Thalassionema, and Pseudo-nitzschia) observed in the field are presented for the midshelf station along the $\mathrm{CH}$ line (Figure 6). Surface water samples (5 m) on 22 May 2001, and from both surface water $(5 \mathrm{~m})$ and the depth of the chl $a$ maximum $(12 \mathrm{~m})$ on 25 May 2001, show distinct heterogeneity in diatom community composition in both time and space. All genera are present at low and nearly equal cell numbers in surface waters on 22 May (Figure 6a), but by 25 May (Figure 6b), Pseudo-nitzschia cell numbers in surface waters have increased more than eightfold, while Thalassiosira has roughly doubled and Thalassionema is threefold lower. On the same day (25 May: Figure 6B), at two adjacent depths, there is also marked spatial variability among these three diatom genera. Of these genera, Pseudonitzschia dominated surface samples, while at the chl $a$ maximum (12 m), Thalassionema dominated. Thalassiosira cell numbers are 3 times higher in surface waters than at the $\operatorname{chl} a$ maximum, but are relatively low at both depths.

[29] Whole community APA was detected in all but two samples assayed, including surface waters from all stations, and subsurface waters from the stations that displayed a subsurface chl a maximum. Whole community activities were low for the most part (Table 3), with most values ranging from 0.1 to $0.7 \mathrm{nmol}-\mathrm{P} / \mathrm{L} / \mathrm{h}$, but several samples had APA well above this level, ranging up to a maximum of $14.37 \mathrm{nmol}-\mathrm{P} / \mathrm{L} / \mathrm{h}$ at station $\mathrm{CH}-3 / 4$ on one of the three sampling days. When normalized to chl $a$ concentration to obtain specific activities, most samples fall within the range of $0.02-0.5 \mathrm{nmol}-\mathrm{P} / \mu \mathrm{g}$ chl $a / \mathrm{h}$, with the maximum specific activity at $\mathrm{CH}-3 / 4$ of $8.55 \mathrm{nmol}-\mathrm{P} / \mu \mathrm{g}$ chl $a / \mathrm{h}$. When the APA data set is taken as a whole, no relationship is evident between APA and DIP $\left(\mathrm{R}^{2}=0.03\right.$ : plot not shown). Likewise, there is no significant relationship between APA and DIP along the $\mathrm{CH}$ transect (Figure $7 \mathrm{a}: \mathrm{R}^{2}=0.13$ ). In contrast, APA along the $\mathrm{CP}$ line displays a significant inverse correlation with DIP (Figure $7 \mathrm{~b}: \mathrm{R}^{2}=0.77$ ). No relationship was apparent between chl $a$-normalized APA (e.g., specific APA) and DIP, whether the entire data set or subsets along the different transects were examined (plots not shown).

[30] A subset of cell-specific APA data (Table 4), obtained using the ELF-labeling technique, is shown graphically (Figure 8). We focus on station $\mathrm{CH}-3 / 4$, the station for which phytocount data were also presented (Figure 6). As was the case for diatom community composition, spatial and temporal variability is also evident in ELF data from the $5-\mathrm{m}$ and $12-\mathrm{m}$ depths at this station. While the \%ELF positive cells was highest for Thalassiosira in surface waters on 22 May (Figure 8a), by 25 May Thalassiosira and Thalassionema show equal percent of ELF-positive cells in surface waters (Figure 8b); the \%ELF positive Pseudo-nitzschia cells in surface waters was low on both dates. Looking at depth distributions of \%ELF positive cells on 25 May (Figure 8b), roughly $30 \%$ of cells in the genera Thalassiosira and Thalassionema had ELF-detected APA at $5 \mathrm{~m}$, while only $11 \%$ of cells in the genus Pseudo-nitzschia had activity. At $12 \mathrm{~m}$, in contrast, the percentage of ELFpositive cells in the genus Thalassiosira had climbed to $50 \%$, while Thalassionema had dropped to $0 \%$. The percentage of ELF-positive Pseudonitzschia cells at the 12-m chl $a$ maximum is approximately fivefold higher than in 
Table 3. Whole Community Cell-Bound Alkaline Phosphatase Activity (Community APA) for COAST-1 Surface Water and Subsurface Chlorophyll $a(\operatorname{chl} a)$ Maximum

\begin{tabular}{|c|c|c|c|c|c|c|c|}
\hline $\begin{array}{c}\text { Station } \\
\text { Identification }\end{array}$ & $\begin{array}{l}\text { Resample } \\
\text { Number }^{\mathrm{a}}\end{array}$ & $\begin{array}{c}\text { Date } \\
\text { Sampled }^{\mathrm{b}}\end{array}$ & $\begin{array}{c}\text { Water } \\
\text { Depth, }{ }^{\mathrm{c}} \mathrm{m}\end{array}$ & $\begin{array}{c}\text { Community APA, } \\
\text { nmol-P/h }\end{array}$ & $\begin{array}{c}\text { Specific APA, }{ }^{\mathrm{d}} \\
\text { nmol } \mathrm{P} / \mu \mathrm{g} \text { chl } a / \mathrm{hr}\end{array}$ & $\begin{array}{c}\operatorname{chl} a_{,}{ }^{\mathrm{e}} \\
\mu \mathrm{g} / \mathrm{L}\end{array}$ & $\begin{array}{r}\mathrm{DIP},{ }^{\mathrm{f}} \\
\mu \mathrm{M}\end{array}$ \\
\hline CH-1 & 1 & $5 / 20 / 01$ & 5 & 0.20 & 0.05 & 3.81 & 0.72 \\
\hline CH-1 & 3 & $5 / 22 / 01$ & 5 & 0.37 & 0.36 & 1.02 & 1.96 \\
\hline $\mathrm{CH}-1$ & 4 & $5 / 24 / 01$ & 5 & 0.52 & 0.04 & 11.66 & 0.60 \\
\hline CH-1 & 5 & $5 / 25 / 01$ & 5 & 6.28 & 1.36 & 4.61 & 1.37 \\
\hline $\mathrm{CH}-1$ & 5 & $5 / 25 / 01$ & 10 & 3.12 & 0.59 & 5.26 & 1.38 \\
\hline CH-1 & 6 & $5 / 25 / 01$ & 5 & 0.26 & 0.02 & 13.50 & 0.86 \\
\hline CH-1 & 7 & $5 / 26 / 01$ & 5 & 0.42 & 0.07 & 6.53 & 1.75 \\
\hline CH-1 & 7 & $5 / 26 / 01$ & 10 & 0.47 & 0.07 & 6.65 & 1.85 \\
\hline $\mathrm{CH}-3 / 4$ & 1 & $5 / 22 / 01$ & 5 & 0.02 & 0.03 & 0.64 & 0.77 \\
\hline CH-3/4 & 2 & $5 / 25 / 01$ & 5 & b.d. & b.d. & 1.54 & 0.64 \\
\hline CH-3/4 & 2 & $5 / 25 / 01$ & 12 & 14.37 & 8.55 & 1.68 & 0.67 \\
\hline CH-3/4 & 3 & $5 / 27 / 01$ & 5 & 0.24 & 0.28 & 0.87 & 0.46 \\
\hline CH-3/4 & 3 & $5 / 27 / 01$ & 12 & 0.26 & 0.17 & 1.49 & 1.10 \\
\hline CH-6 & 1 & $5 / 21 / 01$ & 5 & 0.08 & 0.25 & 0.31 & 0.18 \\
\hline CH-6 & 2 & $5 / 24 / 01$ & 5 & b.d. & b.d. & 0.27 & 0.24 \\
\hline CH-6 & 2 & $5 / 24 / 01$ & 30 & 0.08 & 0.10 & 0.80 & 0.65 \\
\hline CH-6 & 3 & $5 / 27 / 01$ & 5 & 0.14 & 0.36 & 0.38 & 0.22 \\
\hline CH-6 & 3 & $5 / 27 / 01$ & 30 & 0.83 & 0.93 & 0.89 & 0.49 \\
\hline CP-11 & 1 & $5 / 29 / 01$ & 5 & 0.11 & 0.65 & 0.17 & 0.18 \\
\hline CP-11 & 1 & $5 / 29 / 01$ & 40 & 0.07 & 0.25 & 0.28 & 0.38 \\
\hline CP-2 & 1 & $5 / 28 / 01$ & 5 & 0.12 & 0.02 & 8.46 & 0.18 \\
\hline CP-3 & 1 & $5 / 29 / 01$ & 5 & 0.09 & 0.01 & 9.52 & 0.20 \\
\hline CP-3 & 1 & $5 / 29 / 01$ & 10 & 0.08 & 0.01 & 10.83 & 0.37 \\
\hline CP-5 & 1 & $5 / 30 / 01$ & 5 & 0.27 & 0.05 & 5.44 & 0.01 \\
\hline NHT-1 & 1 & $6 / 01 / 01$ & 5 & 0.45 & 0.03 & 15.30 & 0.86 \\
\hline ST-1 & 1 & $6 / 01 / 01$ & 5 & 10.88 & 1.21 & 9.01 & 1.13 \\
\hline ST-2 & 1 & $6 / 01 / 01$ & 5 & 0.28 & 0.42 & 0.67 & 0.01 \\
\hline ST-2 & 1 & $6 / 01 / 01$ & 35 & 0.39 & 0.41 & 0.95 & 0.55 \\
\hline WY-1 & 1 & $5 / 31 / 01$ & 5 & 0.39 & 0.04 & 11.13 & 0.78 \\
\hline WY-1 & 1 & $5 / 31 / 01$ & 40 & 0.54 & 0.45 & 11.88 & 2.40 \\
\hline WY-2 & 1 & $5 / 31 / 01$ & 5 & 0.26 & 0.35 & 0.74 & 0.08 \\
\hline WY-2 & 1 & $5 / 31 / 01$ & 20 & 0.45 & 0.19 & 2.36 & 0.36 \\
\hline CF-1 & 1 & $6 / 02 / 01$ & 5 & 0.29 & 0.04 & 8.30 & 0.19 \\
\hline CF-1 & 1 & $6 / 02 / 01$ & 10 & 0.69 & 0.11 & 6.5 & 0.92 \\
\hline
\end{tabular}

${ }^{\text {a }}$ Resample number equals 1 when stations were sampled only once. For stations that were sampled multiple times, the resample number denotes the number of times that the station was revisited; for example, Resample 2 refers to the second time a station was visited.

${ }^{\mathrm{b}}$ Dates are given as $\mathrm{m} / \mathrm{dd} / \mathrm{yy}$.

${ }^{\mathrm{c}}$ Depths of $5 \mathrm{~m}$ are surface water samples; depths below $5 \mathrm{~m}$ represent the depth of the subsurface chlorophyll maximum, which was sampled whenever it was present.

${ }^{\mathrm{d}}$ Abbreviation: b.d., below detection.

${ }^{\text {e}}$ Chlorophyll $a$ data are from Wetz and Wheeler [2005].

${ }^{\mathrm{f}} \mathrm{DIP}$ data are for $0.4-\mu \mathrm{m}$ filtrates (see Table 2).

surface waters. Photomicrographs of cells at station $\mathrm{CH}-3 / 4$ on sampling dates 22 May and 25 May show examples of cells with APA (ELF-positive), and those that have no APA (Figure 9).

\section{Discussion}

\subsection{Ruling Out Filtration Artifacts in DOP Quantitation}

[31] The rationale behind measuring TDP and DIP in both $0.4-\mu \mathrm{m}$ and $0.2-\mu \mathrm{m}$ filtrates was to determine whether particles in the $0.4-\mu \mathrm{m}$ filtrate, particularly bacteria, might contribute to the apparent DOP pool through inadvertent cell lysis upon exposure to acidic storage and reaction conditions. Bacterial-sized particles are excluded by $0.2-\mu \mathrm{m}$ filters, whereas some portion of bacterial cells will pass through the $0.4-\mu \mathrm{m}$ filter and be present in the $0.4-\mu \mathrm{m}$ filtrate, so this comparison should be revealing of such an artifact, if it exists. DIP and TDP in $0.4 \mu \mathrm{m}$ and $0.2-\mu \mathrm{m}$ filtrates are tightly linearly correlated with best fit slopes of 0.998 to 1.000 and correlation coefficients $\left(\mathrm{R}^{2}\right)$ of 0.9996 and 0.998 , respectively
(Figures 10a and 10b). DOP in $0.4-\mu \mathrm{m}$ and $0.2-\mu \mathrm{m}$ filtrates are also well correlated, with a slope of 0.94 and an $\mathrm{R}^{2}$ of 0.91 . In this analysis, the $0.2-\mu \mathrm{m}$ filtrates were designated the independent variable because these should not be prone to artifacts resulting from particulate contribution to dissolved $\mathrm{P}$. Y intercepts of the full regressions were small and indistinguishable from zero within error (see caption to Figure 10), so best fit lines were forced through the origin; this approach also yielded a markedly better fit for the DOP regression line.

[32] The tight linear correlation and minimal scatter in TDP and DIP comparisons (Figures 10a and 10b) suggest that contribution of particulate-derived dissolved $\mathrm{P}$ in the $0.4-\mu \mathrm{m}$ filtrate is extremely minor. The contrast between $0.4-\mu \mathrm{m}$ and $0.2-\mu \mathrm{m}$ DOP provides a more sensitive indicator of such an artifact, because excess DOP in the 0.4- $\mu \mathrm{m}$ filtrate as a result of contribution from $<0.4-\mu \mathrm{m}$ particulate matter would constitute a larger fraction of the total DOP pool. Because DOP is derived from the difference between TDP and DIP, and these two numbers tend to be similar (Table 2), there is greater error inherent in DOP concen- 

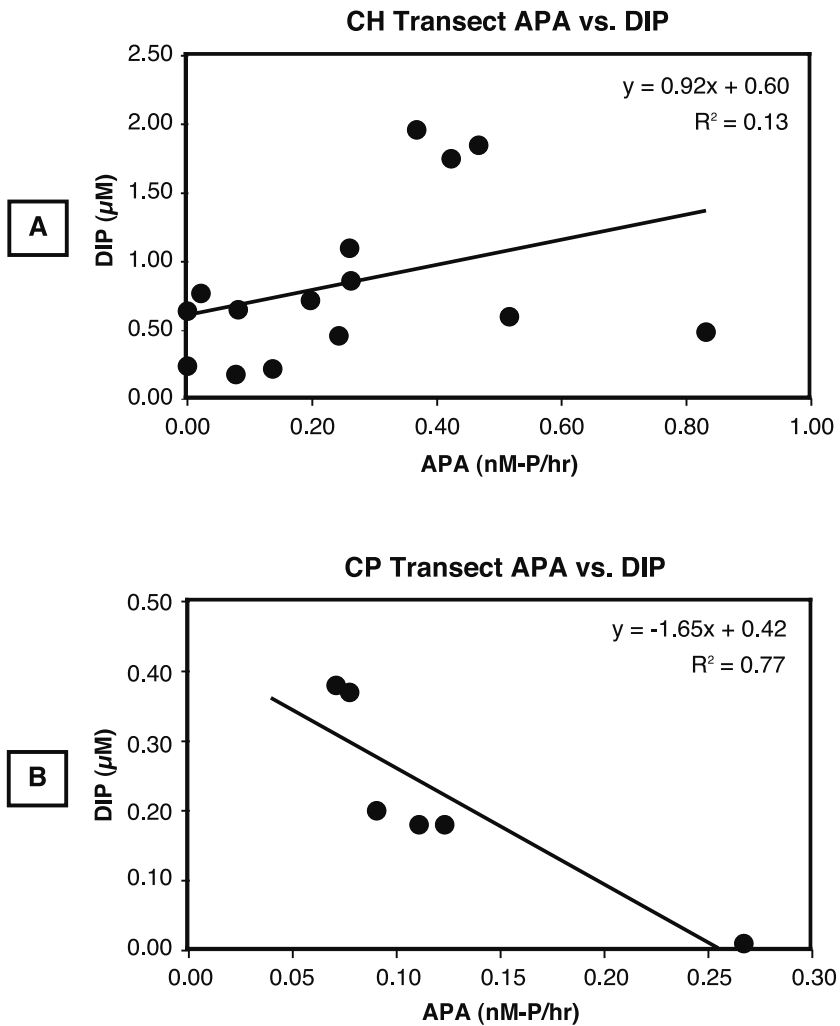

Figure 7. Whole community cell-bound alkaline phosphatase activity (community APA) plotted against DIP concentrations for the (a) $\mathrm{CH}$ transect and (b) $\mathrm{CP}$ transect. For ease of comparison, samples with activity above 1 nmol-P/L/h $(\mathrm{n}=3)$ were excluded from the $\mathrm{CH}$ plot. While no significant relationship exists between APA and DIP along the $\mathrm{CH}$ transect (Figure $7 \mathrm{a}$ ), a negative correlation between APA and DIP is seen along the CP transect (Figure 7b).

trations, which likely explains the greater scatter in the DOP data (Figure 10c). The best fit slope described by the $0.4-\mu \mathrm{m}$ versus $0.2-\mu \mathrm{m}$ filtrate DOP, when all data are included in the analysis, is close to $1\left(0.94 \pm 0.02 ; \mathrm{R}^{2}=0.91\right)$. When outlying data points (12 out of 193 data points) are removed, having been identified statistically as having excessive residuals in the linear regression analysis, the DOP slope even more closely approaches 1.0, and the coefficient improves $\left(0.96 \pm 0.016 ; \mathrm{R}^{2}=0.95\right)$. Errors
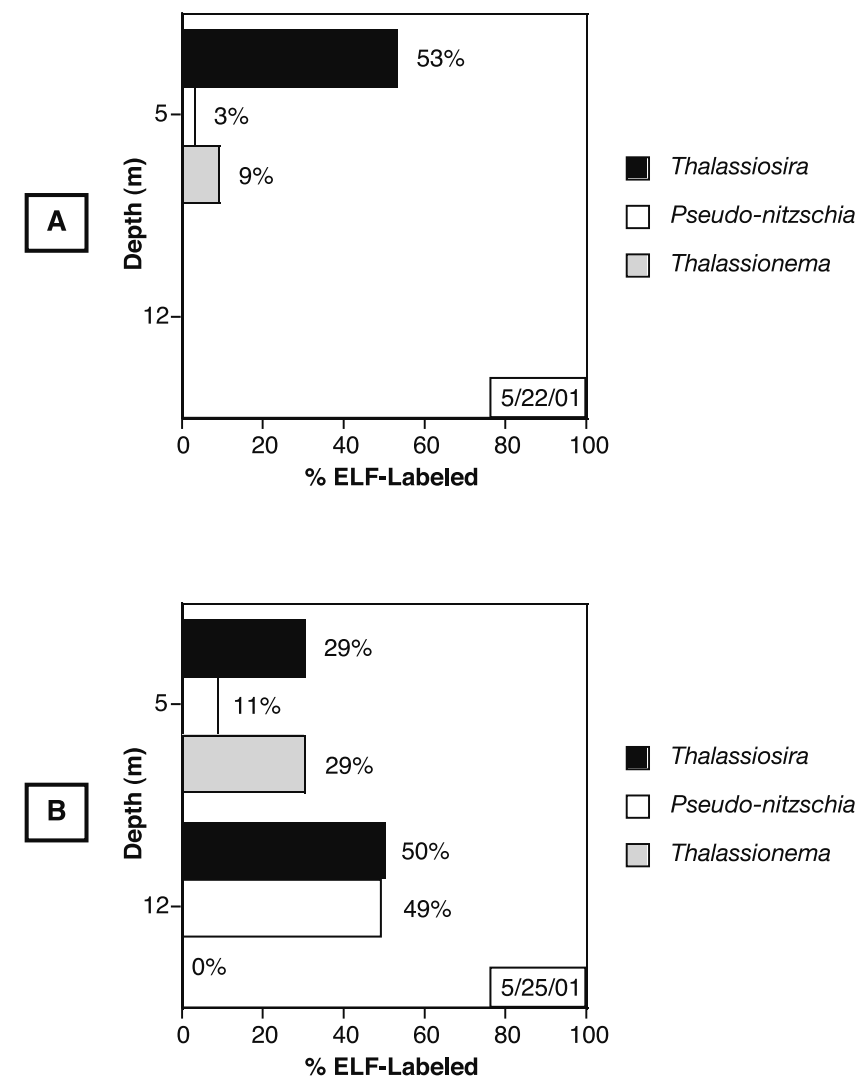

Figure 8. Spatial and temporal variability in percent of ELF-positive diatom cells: Station $\mathrm{CH}-3 / 4$. The percentage of cells of the three common diatom genera, Thalassiosira, Pseudo-nitzschia, and Thalassionema, that assayed positive for the ELF label are shown on two sampling dates: (a) 22 May 2001 (5 m), and (b) 25 May 2001 (5 m and $12 \mathrm{~m}$ ). See Figure 6 for cell numbers, and for description of sample depths.

reported are standard errors. Results of this analysis suggest that $<0.4-\mu \mathrm{m}$-derived particulate matter does not contribute significantly, or in any systematic way, to the $0.4-\mu \mathrm{m}$ DOP filtrate.

\subsection{Physical and Biological Controls on Surface Water Dissolved P Distributions}

[33] There is an extremely high degree of both spatial and temporal variability in the dissolved $\mathrm{P}$ pools within the

Table 4. Diatom Genus Abundance and Percent of Cells in Each Genus That Assayed Positive for ELF Labeling (\%ELF Positive) for Selected COAST-1 Surface Water and Subsurface Depths Where a Subsurface Chlorophyll $a$ (chl $a$ ) Maximum Was Present

\begin{tabular}{|c|c|c|c|c|c|c|c|c|c|c|c|}
\hline \multirow[b]{2}{*}{ Station } & \multirow{2}{*}{$\begin{array}{l}\text { Resample } \\
\text { Number }^{\mathrm{a}}\end{array}$} & \multirow[b]{2}{*}{ Date $^{\mathrm{b}}$} & \multirow{2}{*}{$\begin{array}{c}\text { Water } \\
\text { Depth, m }\end{array}$} & \multirow{2}{*}{$\begin{array}{c}\operatorname{chl} a{ }^{\mathrm{c}} \\
\mu \mathrm{g} / \mathrm{L}\end{array}$} & \multirow{2}{*}{$\begin{array}{r}\mathrm{DIP}^{\mathrm{d}}{ }^{4} \\
\end{array}$} & \multicolumn{3}{|c|}{ Abundance, cells $/ \mathrm{mL}$} & \multicolumn{3}{|c|}{ \%ELF Positive } \\
\hline & & & & & & Thalassiosira & Pseudo-nitzschia & Thalassionema & Thalassiosira & Pseudo-nitzschia & Thalassionema \\
\hline $\mathrm{CH}-1$ & 6 & $5 / 25 / 01$ & 5 & 13.5 & 0.86 & 76.4 & 82.5 & 55.2 & 7 & 4 & 0 \\
\hline $\mathrm{CH}-1$ & 7 & $5 / 26 / 01$ & 5 & 6.53 & 1.75 & 458.4 & 62.5 & 58.3 & 24 & 29 & 5 \\
\hline $\mathrm{CH}-3 / 4$ & 1 & $5 / 22 / 01$ & 5 & 0.64 & 0.77 & 3.5 & 6.9 & 5.2 & 53 & 3 & 9 \\
\hline $\mathrm{CH}-3 / 4$ & 2 & $5 / 25 / 01$ & 5 & 1.54 & 0.64 & 6.9 & 56.3 & 1.7 & 29 & 11 & 29 \\
\hline $\mathrm{CH}-3 / 4$ & 2 & $5 / 25 / 01$ & 12 & 1.68 & 0.67 & 2.3 & 34.0 & 44.0 & 50 & 49 & 0 \\
\hline CP-5 & 1 & $5 / 30 / 01$ & 5 & 5.44 & 0.01 & 66.1 & 2604.3 & 49.6 & 7 & 14 & 25 \\
\hline
\end{tabular}

${ }^{a}$ Resample number equals 1 when stations were sampled only once. For stations that were sampled multiple times, the resample number denotes the number of times that the station was revisited; for example, Resample 2 refers to the second time a station was visited.

${ }^{b}$ Dates are given as $\mathrm{m} / \mathrm{dd} / \mathrm{yy}$.

${ }^{\mathrm{c}}$ Chlorophyll data are from Wetz and Wheeler [2005].

${ }^{\mathrm{d}}$ DIP data are for $0.4 \mu \mathrm{m}$ filtrates (see Table 2). 
Mid-Shelf Station $\mathrm{CH}-3 / 4$

A
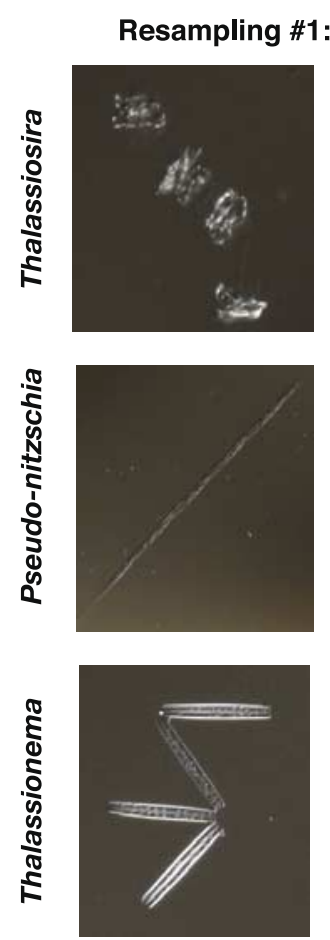

B

Resampling \#2: 5/25/01 (5-m)
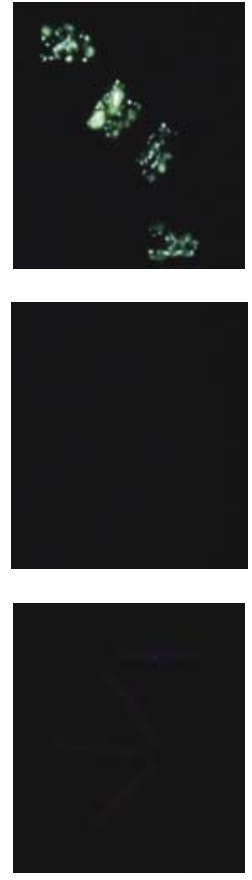
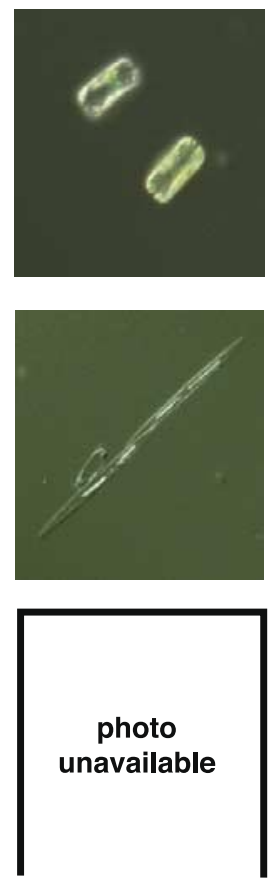
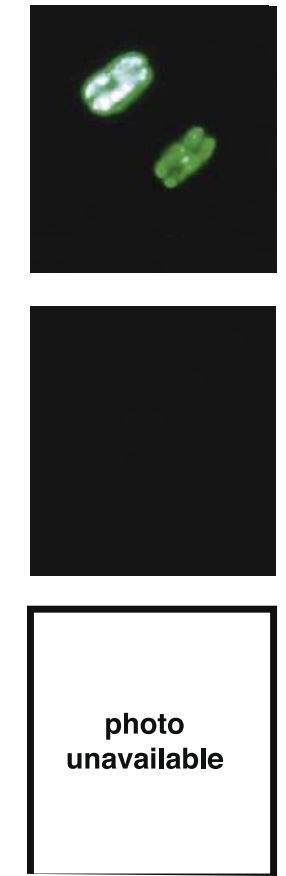

C

Resampling \#2: 5/25/01 (12-m)
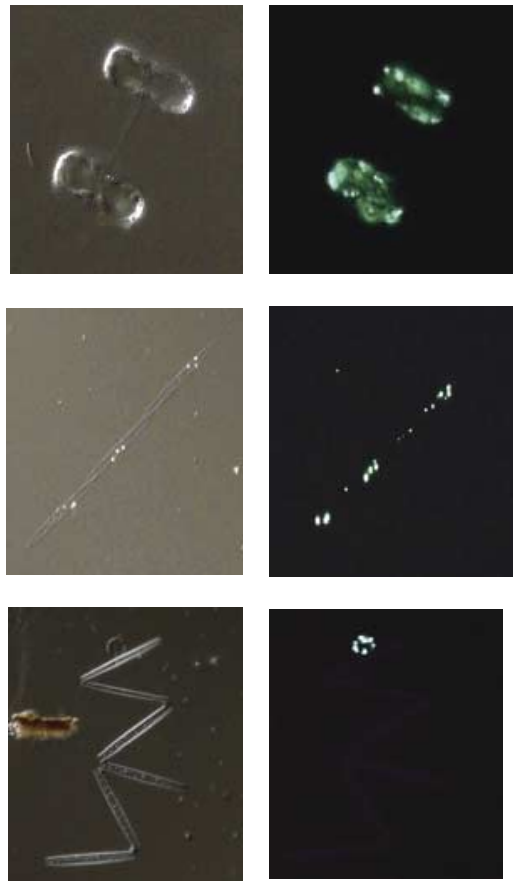

Figure 9. Photomicrographs of ELF-assayed cells. Images of the diatom genera, Thalassiosira, Pseudo-nitzschia, and Thalassionema, are from station CH-3/4: (a) Resampling 1 (22 May 2001, 5 m), (b) Resampling 2 (25 May 2001, $5 \mathrm{~m}$ ), and (c) Resampling 2 (25 May 2001, $12 \mathrm{~m}$ ). Left panels are brightfield images, and right panels are DAPI-long pass images to visualize the ELF-APA fluorescence. Note that bright green fluorescence in right panels is indicative of activity (Thalassiosira), (Figures 9a, 9b, and 9c), and Pseudo-nitzschia (Figure 9c), whereas left panels show chlorophyll autofluorescence only, indicative of a lack of activity.

COAST grid, driven by the dynamic nature of upwellingrelaxation cycles occurring during spring and summer, and the biological response to upwelled nutrients.

\subsubsection{Surface Water Temporal Variability}

[34] The inshore station along the $\mathrm{CH}$ line, which was resampled 7 times over a 7-day period, provides a clear example of the timescale and magnitude of temporal variability in surface water DIP and DOP that can occur in response to upwelling and relaxation events (Figure 3). DIP co-varies in a systematic way with temperature (Figure $3 \mathrm{a}$ ) and chl $a$ (Figure $3 b$ ) in response to upwelling. Upwelling events are characterized by colder temperatures, high DIP concentrations, and low chl $a$. Following upwelling of cold, high-DIP and low chl $a$ water, relaxation is characterized by warming of surface waters, and DIP drawdown accompanied by an increase in chl $a$ (Figures $3 \mathrm{a}$ and $3 \mathrm{~b}$ ), as phytoplankton utilize DIP to synthesize new biomass. In contrast to DIP, which varies inversely with temperature and chl $a$, DOP tracks temperature and chl $a$ (Figures $3 \mathrm{c}$ and 3d). During upwelling events, the colder, deeper water that crops out at the surface is low in DOP, while during relaxation DOP increases apace with chl $a$, suggesting that phytoplankton are a source of DOP either directly through excretion, or indirectly through grazing and microbial mineralization. Thus the fluctuations in DIP and DOP observed over this 1-week period are controlled by the coordinated interplay of physical (upwelling/relaxation) and biological (DIP uptake, DOP production) factors.

\subsubsection{Surface Water Spatial Variability}

[35] Surface water DIP concentrations are highest at nearshore stations all along the sampling grid (Figure 2a), reflecting the fact that upwelled deep, nutrient rich waters crop out close to shore (Figure 1). DIP variability observed along the $\mathrm{CH}$ line during the 7-day resampling period encompasses almost the entire range of variability $(>0.1-$ $2.0 \mu \mathrm{M})$ seen in the entire sampling grid. The only stations that fall outside this range are the midshelf stations on Heceta Bank, which are drawn down to near detection limits (detection limit for DIP $=0.03 \mu \mathrm{M}$ ). The fact that multiple daily sampling of three stations along one transect line shows nearly as much variability as is seen grid-wide indicates that one-time, synoptic sampling of a station grid in a coastal field area, which is arguably the most common sampling strategy adopted in coastal oceanographic field studies, may provide a "snapshot" of nutrients and other biogeochemical parameters that cannot be generalized over longer (e.g., seasonal) timescales.

[36] The shore-perpendicular trends in DIP show systematically lower concentrations in offshore relative to nearshore stations. This pattern is a direct result of the offshore 
A
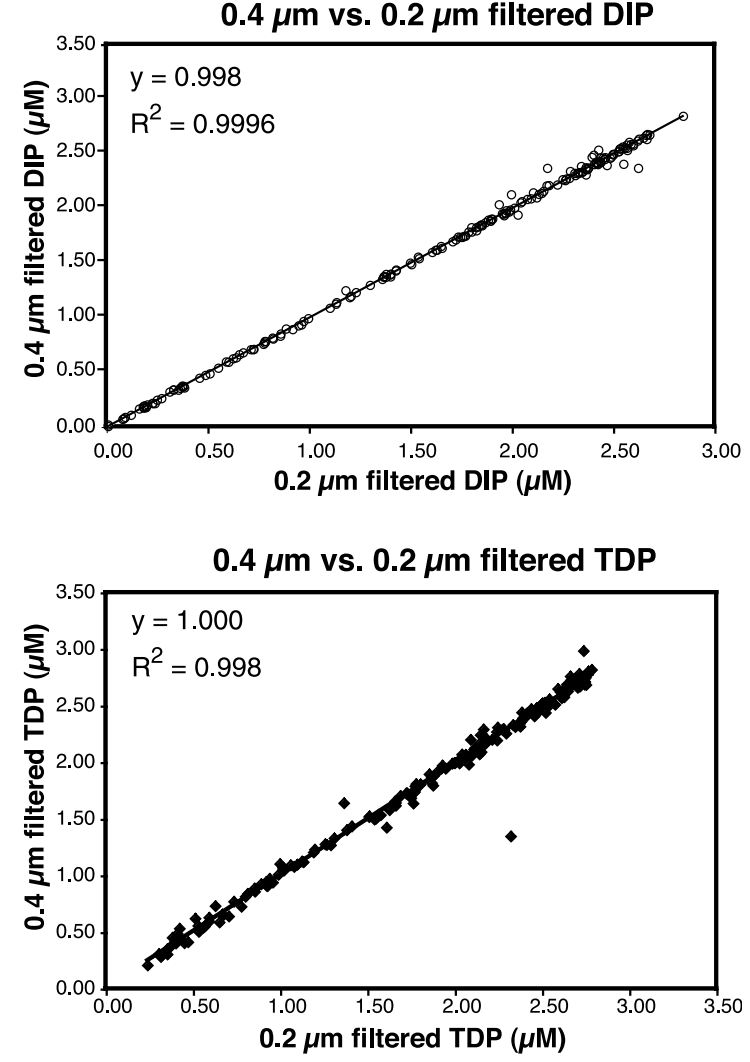

$0.4 \mu \mathrm{m}$ vs. $0.2 \mu \mathrm{m}$ filtered DOP

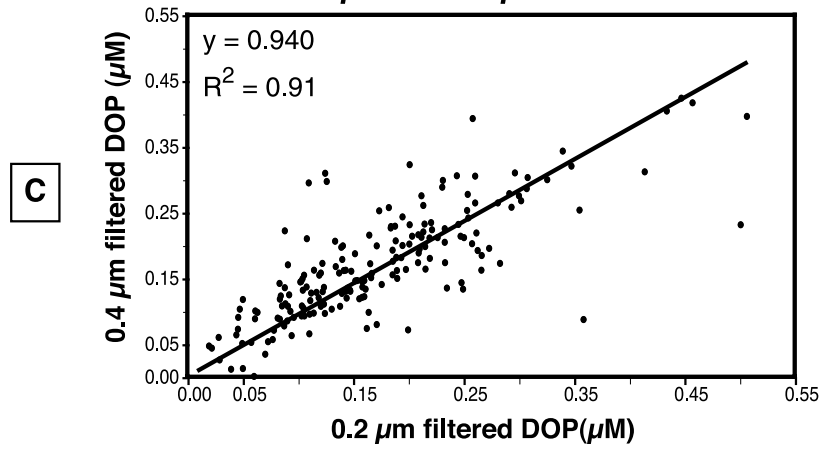

Figure 10. Comparison of (a) DIP, (b) TDP, and (c) DOP concentration data obtained from $0.4-\mu \mathrm{m}$ versus $0.2-\mu \mathrm{m}$ filtrates from all COAST-1 samples. The different filtrates of all three pools are well correlated with slopes indistinguishable from 1.0 in the case of DIP (Figure 10a) and TDP (Figure 10b), and exceedingly close to 1.0 in the case of DOP (Figure 10c). Slopes shown in the figure were forced through the origin because y intercepts were small and indistinguishable from zero within error: $\mathrm{y}=(0.003 \pm$ $0.006)+(0.996 \pm 0.003) x$ for TDP, $y=(0.009 \pm 0.015)+$ $(0.996 \pm 0.008) x$ for DIP. Slope for DOP is much closer to 1 when it is forced through the origin (Figure 10c), particularly when outliers are omitted (see text). Errors reported are standard errors; sample size is $\mathrm{n}=193$.

transport of surface waters driven by the upwelling regime. The lower DIP levels observed at midshelf and offshore stations are accompanied by higher temperatures (Figures 1 and 2; Table 2), reflecting a longer residence time of these waters at the surface, and thus a longer time elapsed since they were upwelled near the coast. The DIP drawdown that occurs once waters are upwelled (e.g., Figure 3 ) results in the lower DIP observed in waters advected offshore.

[37] DIP concentrations along the $\mathrm{CH}$ line are markedly higher than those observed in more southerly stations, especially south of the Stonewall transect where Heceta Bank begins to widen substantially (Figure 2a). The flushing time of waters along the $\mathrm{CH}$ line, where the shelf is narrow and the bathymetry simple, is substantially shorter than on Heceta Bank in the vicinity of the CP line, where flow velocities are weaker [Castelao and Barth, 2005]. Barth et al. [2005] estimate that while the open shelf typified by the $\mathrm{CH}$ line may be flushed on the order of days or less, flushing times on Heceta Bank may be longer by an order of magnitude, such that waters may recirculate around Heceta Bank for $\sim 10$ days before being advected offshore. Thus the residence time of water is longer over Heceta Bank, allowing a more protracted time for DIP drawdown during phytoplankton production, prior to offshore advection. It is this longer residence time that gives rise to the lower surface water DIP levels observed in the southern part of the sampling grid, over Heceta Bank.

[38] As was pointed out in the previous section, correlation of surface water DOP with chl $a$ (Figure 3) suggests that DOP is produced by phytoplankton. Thus the spatial distribution of DOP is expected to track that of chl $a$, reaching highest levels where phytoplankton production and thus chl $a$ concentrations are highest, and vice versa. The spatial distribution of DOP generally follows this pattern, attaining highest levels at nearshore stations where DIP and thus chl $a$ concentrations are highest (Figure 2a; Tables 2 and 3), and dropping to lower levels with distance offshore. The shore-perpendicular DOP trends are less pronounced than those observed for DIP. A number of phenomena could explain the depressed nearshore-offshore gradient, and three possibilities are presented here. In addition to DOP production, it is likely that some portion of the phytoplankton community also consumes DOP (see discussion of alkaline phosphatase activity, below). If the rate of DOP consumption is slower than the rate of DIP drawdown, the contrast between nearshore and offshore DOP concentrations will be damped relative to that seen for DIP. Alternatively, it is possible that some fraction of the DOP pool is not bioavailable, and thus DOP levels can be drawn down just so far and no farther. The levels observed in offshore surface waters thus may reflect the lower limit of DOP utilization. It is also possible that the rate of DOP production/consumption differs in nearshore versus offshore stations owing to differences in phytoplankton and/or bacterial composition, physiology, and resultant differences in DOP consumption and regeneration processes, and rates of these processes. None of these explanations can be ruled out with the present data set.

[39] In stark contrast to the spatial pattern in surface water DIP, overall DOP levels are higher in the more southerly stations of the sampling grid. This is consistent with the lower flushing rates in the southern portion of the grid over Heceta Bank, and the consequent longer residence time of waters in this area. While the longer ( $\sim 10$-day) time span which waters spend recirculating on Heceta Bank [Barth et al., 2005] provides an extended time for phytoplankton 
drawdown of DIP, it also provides a longer time period over which DOP can build up via excretion and/or grazing processes. In contrast, DOP produced along the $\mathrm{CH}$ line will be rapidly advected offshore, and will not have time to build up in the nearshore.

\subsection{Physical and Biological Controls on Depth Distributions of Dissolved $P$}

\subsubsection{General Depth Trends}

[40] The two transects highlighted for discussion in this paper, the $\mathrm{CH}$ and the $\mathrm{CP}$ lines, display similar DIP- and DOP-versus-depth trends in individual profiles for all stations. In general, DIP is lowest in surface waters, reflecting uptake by phytoplankton, while higher DIP at depth reflects regeneration of DIP from sinking particulate organic matter $(\mathrm{POM})$ produced in proximal surface waters, or from water advected onshore at depth that carries DIP regenerated from POM that was produced, sank, and was regenerated outside the sampling grid (Figures 4 and 5). DOP is generally highest in surface waters, and declines to low levels at depth (Figures 4 and 5). Surface water DOP maxima also have been observed in pelagic sites [Karl and Björkman, 2002; Loh and Bauer, 2000; Smith et al., 1986]. In almost all cases the near-surface maximum in DOP concentration in the COAST region coincides with a near-surface maximum in chl $a$ concentrations. This is displayed graphically for the CP transect (Figure 4), where stations CP-2 and CP5 , in particular, show nearly coincident DOP and chl $a$ maxima. This is similar to trends seen on the Eel River Shelf of Northern California [Monaghan and Ruttenberg, 1999], where near-surface DOP maxima were coincident with chl $a$ maxima. The similar depth distributions of DOP and chl a suggest, once again, that consumption and production processes that accompany the phytoplankton are the source of DOP to surface waters. The close coupling of DOP and chl $a$ appears to break down at the most offshore station, CP-11 (Figure 4d), where both chl $a$ and surface DOP concentrations are substantially lower than at nearshore and midshelf stations (note scale differences for chl $a$ data presented in Figure 4).

\subsubsection{Spatial Variability in Depth Trends}

[41] Similar nearshore-offshore trends are observed for both the $\mathrm{CP}$ line and the $\mathrm{CH}$ line. Focusing on the $\mathrm{CP}$ line for simplicity (Figure 4), the mirror image depth profiles of DOP and DIP are apparent across the shelf, but are most smoothly and clearly delineated in the nearshore station CP2 (Figure 4a). Midshelf DOP and DIP depth profiles (CP-3 and CP-5, Figures $4 \mathrm{~b}$ and $4 \mathrm{c}$, respectively) appear to be the composite of distinct strata. The upper layer displays sharper concentration gradients in DIP, DOP, and chl $a$ than the lower layer and, within the lower layer these gradients are intercalated with zones of nearly invariant DIP and DOP concentrations. Depth trends in the offshore station (CP-11, Figure 4d) can also be partitioned into an upper and lower layer, but gradients are more muted within each layer relative to nearshore stations.

[42] In the upper layer, DIP and DOP patterns are dominated by the biological processes of DIP uptake and DOP production and consumption, while gradients in the lower layer are most likely created by advective water motion rather than vertical diffusive processes, whereby waters of relatively homogeneous DIP and DOP are trans- ported in an onshore direction during upwelling events, while undergoing less biological processing of either DIP or DOP relative to surface waters. The increase in DIP and DOP seen in the bottom layer of stations CP-5 and CP-11 may reflect input of DIP and DOP from the underlying seabed, a process also suggested by Loh and Bauer [2000] for deep-water stations in the North Pacific and Southern oceans. Station CP-5 also displays a near-bottom increase in chl $a$, which may reflect bottom sediment resuspension.

[43] Unlike the CP transect, DIP and DOP depth profiles along the $\mathrm{CH}$ transect (Figure 5) do not show clear evidence of stratification. The absence of stratification can be explained by the shorter residence time of water along the $\mathrm{CH}$ line, as previously discussed, where rapid flushing of the narrow northerly shelf prevents evolution of distinct, vertically arrayed water masses. The longer residence time of waters along the $\mathrm{CP}$ transect overlying Heceta Bank, in contrast, permits development of strata that are biogeochemically distinct.

\subsubsection{Temporal Variability in Depth Trends}

[44] While depth profiles along the $\mathrm{CH}$ transect are qualitatively similar to those along the CP transect, the fact that each station was resampled multiple times provides insight into the magnitude of temporal variability that can be observed, and how this varies along a shore-perpendicular transect. The high degree of DIP and DOP variability seen in the nearshore station (Figures 5a and 5d) is a direct result of fluctuating conditions driven by upwelling-relaxation events, the effects of which are most pronounced in the nearshore region. The temporal variability that was so clearly seen in surface waters (Figure 3 ) propagates down to depth at this shallow, nearshore station. The midshore and offshore stations are substantially insulated from the upwelling-relaxation driven fluctuations so clearly manifested in the nearshore station, as evidenced by the smaller degree of variability in DOP (Figures 5b and 5c) and especially DIP (Figures 5e and 5f) depth profiles. Bottom water DIP levels are quite similar for all stations, reflecting the deep source water that is advected inshore at depth, while surface water DIP becomes progressively depleted moving from station $\mathrm{CH}-1$ to more offshore stations. The inverse pattern is observed for DOP, however there is little difference in DOP profiles at the midshore and offshore stations, suggesting that stable DOP concentration levels may have been reached, perhaps indicating a balance between DOP production and consumption at these stations or, alternatively, indicating a residual pool of unreactive DOP. A particularly striking feature of these data is the fact that the variability seen for the nearshore station (Figures 5a and 5d) encompasses the full range of variability seen in the more offshore stations. This high degree of temporal variability again underscores the danger of extrapolating from a synoptically sampled grid, which may provide a snapshot of dissolved $\mathrm{P}$ distributions that are reflective only of a particular time, and may not capture the true range of $\mathrm{P}$ distribution that can occur in dynamic coastal systems such as this one.

\subsection{Linking Dissolved P Distributions With Enzymatic Indicators of DOP Hydrolysis}

[45] Dissolved organic phosphorus molecules are not typically directly bioavailable to phytoplankton [Cembella et al., 1984]. However, phytoplankton can produce phos- 
phophydrolytic enzymes, such as alkaline phosphatase (APase), that cleave orthophosphate from phosphomonoesters, thus producing bioavailable $\mathrm{P}$ from an initially unavailable substrate [Ammerman, 1991; Cembella et al., 1984; Chróst and Overbeck, 1987; Chróst, 1991]. APase is typically an inducible enzyme in phytoplankton, meaning that it is expressed only when the physiological cue, generated by low orthophosphate levels, is triggered in the organism. There are a number of exceptions, however. For example, there are strain differences in the ability to hydrolyze phosphomonoesters, and some taxa may have low-level constitutive activity, meaning that enzyme activity is always present regardless of external or internal P levels [Dyhrman and Palenik, 2003; Gonzalez-Gil et al., 1998; Scanlan and West, 2002]. In the COAST study area, we have documented P-related changes in diatom APA suggesting $\mathrm{P}$ regulation of the enzyme activity [Dyhrman and Ruttenberg, 2005; Ruttenberg and Dyhrman, 2004]. The presence and regulation of APA in this system suggests that the diatoms examined herein have the capacity to utilize phosphomonoesters present in the DOP pool as a source of bioavailable $\mathrm{P}$.

\subsubsection{Whole Community APA}

[46] Analysis of APA in cells concentrated by filtration onto $0.2-\mu \mathrm{m}$ filters provides a measure of the cell-bound APA in the whole community, including all phytoplankton and bacteria trapped on the filter. Thirty-two of the thirtyfour samples assayed had APA (Table 3). Although direct comparison of APA across studies in different environments is difficult because activity is influenced by so many highly variable factors (e.g., community composition, cellular physiology, P biogeochemistry), the activities observed in the COAST study area were generally comparable to those observed in other studies, one from a coastal region and the other from the oligotrophic North Atlantic [Ammerman et al., 2003; Labry et al., 2002]. Much higher activities have been observed, however, in anthropogenically impacted coastal systems (e.g., the high-nitrate Mississippi outflow and Louisiana Shelf [Ammerman and Glover, 2000]) and low P freshwater systems [e.g., Chróst and Overbeck, 1987; Chróst, 1991; Rengefors et al., 2001, 2003].

[47] APase expression is generally triggered by low cellular phosphate levels, which often correspond to low ambient DIP in the host water [Ammerman, 1991; Cembella et al., 1984; Chróst, 1991; Healey and Hendzel, 1980], such that we would expect APA to show a negative correlation to ambient orthophosphate concentrations. Such a relationship has been observed in freshwater [Chróst and Overbeck, 1987; Chróst, 1991] and coastal ocean [Ammerman, 1991; Fourquerean et al., 1993] studies. No such correlation exists for the COAST-1 data set when taken as a whole. An examination of the geographically distinct regions of the study grid, however, permits insight into why such a relationship may not be apparent shelf wide.

[48] Along the northern $\mathrm{CH}$ transect, no systematic correlation between DIP and APA is apparent (Figure $7 \mathrm{a}: \mathrm{R}^{2}=$ 0.13 ), while a significant negative correlation is apparent for stations from the CP transect over Heceta Bank in the south (Figure $7 \mathrm{~b}: \mathrm{R}^{2}=0.77$ ). This is consistent with the two distinct hydrographic regimes that characterize the shelf in the region of the $\mathrm{CH}$ line versus that over Heceta Bank. As was discussed previously, the flushing time on the northern part of the grid, along the $\mathrm{CH}$ line, is rapid: on the order of days or less [Barth et al., 2005; Castelao and Barth, 2005; J. A. Barth, personal communication, 2005]. Thus there may be insufficient time for an anticorrelative relationship between DIP and APA to grow in along the CH transect, as waters are advected away before such a relationship can develop. In contrast, the $\sim 10$-day residence time over Heceta Bank [Barth et al., 2005] could allow ample time for development of a systematic relationship between DIP and APA (Figure 7b). In fact, incubation experiments conducted with samples from this field area suggest that such a relationship is observable within a 5-day timeframe [Dy hrman and Ruttenberg, 2005; Ruttenberg and Dyhrman, 2004].

[49] One particularly striking observation is that APA occurs in cell concentrates from surface waters characterized by relatively high DIP, ranging from a low level of $0.01 \mu \mathrm{M}$ up to $1.96 \mu \mathrm{M}$ DIP (Table 3). In fact, some of the highest activities observed occur in samples with DIP concentrations in excess of $1 \mu \mathrm{M}$. These observations raise the question of why the phytoplankton synthesize APase, an energetically taxing process, when ambient DIP levels should be adequate to fulfill their phosphate demand? We offer three possible explanations for this apparent paradox. The samples exhibiting APA in relatively high-DIP waters may reflect microscale variability in the dissolved phosphorus field. It may be that DIP is depleted in the near vicinity (nanoscale to micrometer scale) of individual cells, a feature that is not resolvable with bulk water DIP concentration measurements. The cell thus experiences a DIP-depleted microenvironment and mounts the phosphate stress response of up-regulating APA, despite the fact that DIP in the bulk of the water beyond the microzone adjacent to the cell is relatively high. This notion of microscale features in biogeochemistry and physiology has been articulated previously [Azam, 1998; Azam and Worden, 2004; Dyhrman and Palenik, 2001]. An alternative explanation is that presence of APA in relatively high DIP waters reflects the nutritional history of the cell. In other words, the waters in which the cell was stimulated to produce APA had a different (and lower) DIP level than the waters in which the cell was collected. One sample that fits this explanation particularly well is the 40-m sample at Station WY-1, which has APA of $0.54 \mathrm{nmol}-\mathrm{P} / \mathrm{L} / \mathrm{h}$ at a DIP of $2.40 \mu \mathrm{M}$ (Table 3 ). This sample was collected immediately above the seabed, and is likely enriched in DIP owing to diffusive input of DIP from bottom sediments. Thus, while the cells were presumably mixed down from the surface, retaining the physiological signature of $\mathrm{P}$ stress due to lower surface water DIP, the ambient DIP has been augmented by diffusive input from the seabed. A third possibility is that the kinetics of phosphate uptake, which often differ substantially between different phytoplankton species [Cembella et al., 1984], and the cycling rate of the DIP standing stock, will influence a species' ability to compete for DIP in a given environment, and thus influence species-specific P stress response mechanisms like the upregulation of APA. None of these explanations are mutually exclusive of the others, and one or more may be operating simultaneously.

\subsubsection{Cell-Specific Alkaline Phosphatase Analysis}

[50] Whole community APA rates, such as those discussed above, provide insight into potential DOP hydrolysis and bioavailability to the entire community. However, the enzyme 
is found in many organisms, including both heterotrophic bacteria and phytoplankton; thus whole community rates do not allow estimation of the APA contribution from primary producers. To address this ambiguity, we also examined APA associated with specific phytoplankton taxa using Enzyme Labeled Fluorescence (ELF). ELF fluorescently tags individual cells with APA, enabling identification of those members of the phytoplankton community that are contributing to the whole community APA. ELF offers superior resolution to size fractionation, in that ELF can identify single-cell activity in organisms of the same size class. The ELF technique is being increasingly used to identify cell-specific APA in field populations from marine and freshwater environments [Carlsson and Caron, 2001; Dyhrman and Palenik, 1999; Dyhrman et al., 2002; Rengefors et al., 2001, 2003].

[51] ELF analysis revealed that a number of diatom genera display APA, and that there is substantial heterogeneity in APA among genera. For example, the midshelf station CH-3/4 was resampled on 22 May and 25 May, and the distribution of diatoms exhibiting APA was markedly different in surface waters on both these days (Figure 8a and $8 b)$. Likewise, the distribution of APA on the same day ( 25 May), between surface water $(5 \mathrm{~m})$ and the depth of the chl $a$ maximum $(12 \mathrm{~m})$, is substantially different (Figure $8 \mathrm{~b}$ ). Note that there was no chl $a$ maximum on 22 May (Table 2). Differences in APA between genera can result from several factors, including the potential for DIP storage and differences in regulation of APA in different microbes. The ELF assay reveals that APA in cells within the same genus can vary, as well, with positive and negative cells occurring in the same sample. The observed differences in ELF-APA exist at $5 \mathrm{~m}$ on two different dates, and between 5 and $12 \mathrm{~m}$ on the same date, despite the fact that ambient DIP for on these dates was relatively high and similar (Table 3: 0.64$0.77 \mu \mathrm{M})$. The potential for small-scale heterogeneity in phytoplankton cellular physiology is a topic that is only recently being addressed as new cell-specific methods like ELF assays are applied to field populations. As was discussed previously for the whole community APA data, possible explanations for the variability in physiology could be attributed to small-scale differences in the nutrient environment of the cells, or differences in the nutritional history of individual cells.

[52] One of the most noteworthy observations in this field study has been the degree of small-scale heterogeneity in both space and time not only of dissolved $\mathrm{P}$ pools (see earlier discussion), but of phytoplankton biomass (inferred from chl a), phytoplankton community composition, and phytoplankton phosphorus physiology as revealed by metrics of DOP hydrolysis (i.e., ELF-APA).

\subsection{Importance of Linking Biogeochemistry to the Physical Regime}

[53] Biogeochemical parameters such as dissolved P, whole community APA and ELF APA in surface waters at midshelf station $\mathrm{CH}-3 / 4$, which is removed from the site of the most intense upwelling, reflect the cumulative biogeochemical processes initiated in the nearshore zone of upwelling, in addition to those that continue as surface water is advected offshore. In order to fully understand the physiological status of the phytoplankton with respect to $\mathrm{P}$ demand, the biogeochemical features observed at a given location at a given time must be explicitly linked with a comprehensive view of the hydrography of the study area. For example, manifestation of APA in an algal cell is a response not only to current ambient conditions, but also reflects the past history of the cell. Thus, while upwelling conditions were present on 22 May, as indicated by low surface water temperatures at nearshore station $\mathrm{CH}-1$ (Figure 3), the midshelf station $\mathrm{CH}-3 / 4$ on this date most likely reflects relaxation conditions that characterized the nearshore on the previous day (Figure 3). Likewise, while relaxation characterizes the nearshore on 25 May (Figure 3), midshelf station $\mathrm{CH}-3 / 4$ more likely reflects the tail end of the previous upwelling period, and thus hosts postupwelling water being advected offshore. Consistent with this scenario, surface water chl $a$ is a factor of two higher at CH-3/4 on 25 May than it is on 22 May (Table 4); DIP is lower and DOP is higher on 25 May relative to 22 May (Tables 2 and 4). The pursuit of a coupled physicalbiogeochemical study that would allow such an analysis to proceed at a quantitative level is beyond the scope of the present paper, but clearly is the next step in understanding $\mathrm{P}$ cycling and biological response in this upwellingdominated system.

\section{Conclusions}

[54] Patterns of nutrient delivery to coastal systems, the role of dissolved organic nutrients in supporting primary production in the coastal ocean, and the role of productive coastal margins in transport of dissolved and particulate organic matter to the open ocean, are topics currently under intense scrutiny. Given recent observations on the importance of phosphorus in various oceanic regimes, and the large contribution of the coastal ocean to global production, there is heightened motivation to understand $\mathrm{P}$ biogeochemistry and bioavailability in coastal systems. As most carbon burial in the oceans occurs on the continental margins ( $>80 \%$ [Berner, 1982; Hedges and Keil, 1995]), it is of fundamental importance to understand the mechanisms driving nutrient supply to these productive regions.

[55] The high spatial- and temporal-resolution sampling and analysis of dissolved P pools (DIP, DOP), whole community and single cell alkaline phosphatase activity, and phytoplankton community composition, all reveal a high degree of heterogeneity in space and time in the upwelling-dominated Oregon Shelf study region. Daily resampling of a nearshore station over a 1-week period revealed that surface water DIP and DOP co-vary in systematic, but opposing ways with changing temperature and chl $a$, with changes in DIP varying inversely with temperature and chl $a$, while DOP changes parallel temperature and chl $a$. These fluctuations in surface water DIP and DOP are controlled by the coordinated interplay of physical (upwelling/relaxation) and biological (DIP uptake, DOP production) factors. The coincidence of highest DOP with high chl $a$ concentrations suggests that phytoplankton are an important source of DOP. At the same time, however, the presence of alkaline phosphatase activity in phytoplankton suggests the potential for enzymatic DOP hydrolysis and production of bioavailable DIP from an initially unavailable substrate. Evidence for simultaneous production and poten- 
tial consumption of DOP by phytoplankton need not be viewed as paradoxical, as it may be that certain groups within the phytoplankton are responsible for production while others may be more active in enzymatic DOP hydrolysis and subsequent DIP uptake. Artifacts in DOP concentration from $0.4-\mu \mathrm{m}$ filtrates due to bacterial cell lysis appear to be minimal.

[56] Examination of one resampled station reveals changes in phytoplankton biomass and community composition, and in levels of whole community and cell-specific (ELF) APA, on a timescale of days. ELF analysis revealed that a number of diatom genera display APA, and that there is substantial heterogeneity in APA both among and within genera. The observation of APA in surface waters with relatively high DIP, as well as the variability in APA observed at the whole community and at the single cell level, could result from microscale differences in the nutrient environment of cells, or differences in the nutritional history of cells.

[57] Mirror-image depth profiles of DIP and DOP illustrate the different processes that control the presence and distribution of these dissolved P pools. While DIP concentrations are lowest in surface water and increase with depth, reflecting biological uptake at the surface and regeneration at depth, as well as advection of deep nutrient-rich water from offshore, DOP concentrations display the opposite trend. High surface water DOP reflects production via excretion and/or grazing; the low levels observed at depth indicate extensive remineralization of DOP must occur, preventing accumulation in deeper waters. Variability in DIP and DOP profiles observed at one station over a 1-week period nearly encompasses the range of concentrations observed throughout the COAST sampling grid, indicating that temporal variability can be similar in magnitude to spatial variability, and emphasizing the risk of extrapolating, in time or space, from single time-point sampling.

[58] The high degree of temporal variability observed in dissolved P pools, phytoplankton biomass, phytoplankton community composition, and phytoplankton phosphorus physiology, illustrates clearly the patchiness that characterizes biogeochemical parameters in the coastal ocean. Onetime, synoptic sampling of a coastal system very likely will provide a snapshot of biogeochemical distributions that will not reflect the true range of distributions that can occur over timescales as short as days-to-weeks. Extrapolation from a synoptically sampled grid to longer timescales, such as seasonal timescales, is likely even more risky.

[59] The physical regime in the northernmost portion of the study area differed substantially from that in the southern portion, as a result of different flushing times driven by the contrast in bathymetry of the two regions. The higher rate of flushing on the narrow northern shelf prevented the extensive DIP drawdown and the high buildup of DOP that was observed over the broader shelf in the south, over Heceta Bank. Further, the shorter residence time of water over the northern transect did not allow the evolution of a relationship between DIP and APA, while this relationship was clearly present over Heceta Bank, where residence time of water is substantially longer. Thus patterns of biogeochemical parameters are profoundly influenced by bathymetry and the physical regime, as is clearly seen in the dissolved P, APA, and phytoplankton community composi- tion data presented here. A quantitative treatment of the physical-biogeochemical linkages will be addressed in future work, a goal made possible by the multidisciplinary COAST platform.

[60] Acknowledgments. The authors would like to acknowledge the scientists of the COAST project, particularly Pat Wheeler and Jack Barth (OSU), who encouraged and then greatly facilitated our involvement with the COAST project. We gratefully acknowledge the assistance at sea of Christie Haupert and Kari Paro, who made possible the collection of the samples discussed in this paper. Eileen Monaghan and Tori Ziemann are acknowledged for production of dissolved P data, and Sheean Haley for production of whole community APA data. Pat Wheeler (OSU) is acknowledged for providing access to unpublished chlorophyll $a$ data, and Telu Li (UH) for assistance with statistical analyses. KCR acknowledges WHOI for rapid-response funding that made possible participation on this first COAST cruise, and NSF-OCE grant 0119134 for support of subsequent work on these and other COAST samples. This is SOEST contribution 6597.

\section{References}

Ammerman, J. W. (1991), Role of ecto-phosphohydrolases in phosphorus regeneration in estuarine and coastal ecosystems, in Microbial Enzymes in Aquatic Environments, edited by R. J. Chróst, pp. 165-185, Springer, New York.

Ammerman, J. W., and W. B. Glover (2000), Continuous underway measurement of microbial ectoenzyme activities in aquatic ecosystems, Mar. Ecol. Prog. Ser., 201, 1-12.

Ammerman, J. W., R. R. Hood, D. A. Chase, and J. B. Cotner (2003), Phosphorus deficiency in the Atlantic: An emerging paradigm in oceanography, Eos Trans. AGU, 84, 165,170.

Azam, F. (1998), Microbial control of oceanic carbon flux: The plot thickens, Science, 280, 694-696.

Azam, F., and A. Z. Worden (2004), Microbes, molecules, and marine ecosystems, Science, 303, 1622-1624.

Barth, J. A., and P. A. Wheeler (2005), Introduction to special section: Coastal Advances in Shelf Transport, J. Geophys. Res., doi:10.1029/ 2005JC003124, in press.

Barth, J. A., S. D. Pierce, and R. Castelao (2005), Time-dependent, winddriven flow over a shallow mid-shelf submarine bank, J. Geophys. Res., doi:10.1029/2004JC002761, in press.

Berner, R. A. (1982), Burial of organic carbon and pyrite sulfur in the modern ocean: Its geochemical and environmental significance, Am. J. Sci., 282, 451-473.

Bidigare, R. R. (1991), Analysis of algal chlorophylls and carotenoids, in Marine Particles: Analysis and Characterization, Geophys. Monogr. Ser., vol. 63, edited by D. C. Hurd and D. W. Spencer, pp. 119-124, AGU, Washington, D. C

Björkman, K., and D. M. Karl (2003), Bioavailability of dissolved organic phosphorus in the euphotic zone at Station ALOHA, North Pacific Subtropical Gyre, Limnol. Oceanogr., 48, 1049-1057.

Butler, E. I., S. Knox, and M. I. Liddicoat (1979), The relationship between inorganic and organic nutrients in seawater, J. Mar. Biol. Assoc. U. K., $59,239-250$

Carlsson, P., and D. A. Caron (2001), Seasonal variation of phosphorus limitation of bacterial growth in a small lake, Limnol. Oceanogr., 46, $108-120$.

Castelao, R. M., and J. A. Barth (2005), Coastal ocean response to summer upwelling favorable winds in a region of alongshore bottom topography variations off Oregon, J. Geophys. Res., C10S04, doi:10.1029/ 2004JC002409.

Cembella, A. D., N. J. Antia, and P. J. Harrison (1984), The utilization of inorganic and organic phosphorus compounds as nutrients by eukaryotic microalgae: A multidisciplinary perspective, CRC Crit. Rev. Microbiol., Part 1, 10, 317-391.

Chróst, R. J. (1991), Environmental control of the synthesis and activity of aquatic microbial ectoenzymes, in Microbial Enzymes in Aquatic Environments, edited by R. J. Chróst, pp. 29-59, Springer, New York.

Chróst, R. J., and J. Overbeck (1987), Kinetics of alkaline phosphatase activity and phosphorus availability for phytoplankton and bacterioplankton in Lake Plussee (north German eutrophic lake), Microbial Ecol., 13, $229-248$

Dyhrman, S. T., and B. Palenik (1999), Phosphate stress in cultures and field populations of the Dinoflagellate Prorocentrum minimum (Dinophycaea), Appl. Environ. Microbiol., 65, 3205-3212.

Dyhrman, S. T., and B. Palenik (2001), A single-cell immunoassay for phosphate stress in the Dinoflagellate Prorocentrum minimum detected by a single-cell alkaline phosphatase assay, J. Phycol., 37, 400-410. 
Dyhrman, S. T., and B. Palenik (2003), A characterization of ectoenzyme activity and phosphate-regulated proteins in the coccolithophorid Emiliania huxleyi, J. Plankton Res., 25, 1-11.

Dyhrman, S. T., and K. C. Ruttenberg (2005), The presence and regulation of alkaline phosphatase activity in eukaryotic phytoplankton from the coastal ocean: Implications for dissolved organic phosphorus remineralization, Limnol. Oceanogr, in press.

Dyhrman, S. T., E. A. Webb, D. Anderson, J. Moffett, and J. Waterbury (2002), Cell specific detection of phosphorus stress in Trichodesmium from the western North Atlantic, Limnol. Oceanogr., 47, 1832-1836.

Fourquerean, J. W., R. D. Jones, and J. C. Zieman (1993), Processes influencing water column nutrient characteristics and phosphorus limitation of phytoplankton biomass in Florida Bay, FL, USA: Inferences from spatial distributions, Estuarine Coastal Shelf Sci., 36, 295-314.

Gonzales-Gil, S., B. Keafer, R. V. M. Jovine, and D. M. Anderson (1998), Detection and quantification of alkaline phosphatase in single cells of phosphorus-limited marine phytoplankton, Mar. Ecol. Prog. Ser., 164, $21-35$.

Hales, B., J. Moum, P. Covert, and A. Perlin (2005), Irreversible nitrate fluxes due to turbulent mixing in a coastal upwelling system, J. Geophys. Res., 110, C10S11, doi:10.1029/2004JC002685.

Healey, F. P., and L. L. Hendzel (1980), Physiological indicators of nutrient deficiency in lake phytoplankton, Can. J. Fish. Aquat. Sci., 37, 442-453.

Hedges, J. I., and R. G. Keil (1995), Sedimentary organic-matter preservation-An assessment and speculative synthesis, Mar. Chem., 49, 81-115.

Hudson, J. J., W. D. Taylor, and D. W. Schindler (2000), Phosphate concentrations in lakes, Nature, 406, 54-56.

Jackson, G. A., and P. M. Williams (1985), Importance of dissolved organic nitrogen and phosphorus to biological nutrient cycling, Deep Sea Res., $32,223-235$

Karl, D. M., and K. Björkman (2002), Dynamics of DOP, in Biogeochemistry of Marine Dissolved Organic Matter, edited by D. A. Hansell and C. A. Carlson, pp. 249-366, Elsevier, New York.

Karl, D. M., J. E. Dore, D. V. Hebel, and C. Winn (1991), Procedures for particulate carbon, nitrogen, phosphorus and total mass analyses used in the US-JGOFS Hawaii Ocean Time-Series Program, in Marine Particles: Analysis and Characterization, Geophys. Monogr. Ser., vol. 63, edited by D. C. Hurd and D. W. Spencer, pp. 71-78, AGU, Washington, D. C.

Karl, D. M., K. Björkman, J. Dore, L. Fujieki, D. Hebel, T. Houlihan, R. Letelier, and L. Tupas (2001), Ecological nitrogen-to-phosphorus stoichiometry at station ALOHA, Deep Sea Res., Part II, 48, 1529-1566.

Karp-Boss, L., P. Wheeler, B. Hales, and P. Covert (2004), Distributions and variability of particulate organic matter in a coastal upwelling system, J. Geophys. Res., 109(C9), C09010, doi:10.1029/2003JC002184.

Koroleff, F. (1983), Determination of phosphorus, in Methods of Seawater Analysis, edited by K. Grasshoff, M. Ehrhardt, and K. Kremling, pp. 117-156, Verlag-Chimie, New York.

Krom, M., N. Kress, S. Brenner, and L. Gordon (1991), Phosphorus limitation of primary production in the eastern Mediterranean, Limnol. Oeanogr., 36, 424-432.

Labry, C., A. Herbland, and D. Delmas (2002), The role of phosphorus on plankton production of the Girone plume waters in the Bay of Biscay, J. Plankton Res., 24, 97-117.

Loh, A. N., and J. E. Bauer (2000), Distribution, partitioning and fluxes of dissolved and particulate organic C, N and P in the eastern North Pacific and Southern Oceans, Deep Sea Res., Part I, 47, 2287-2316.

Lyman, J., and R. H. Fleming (1940), Composition of sea water, J. Mar. Res., 3, 134-146.
Matrai, P. (1991), Determination of $\mathrm{S}$ in marine particles, in Marine Particles: Analysis and Characterization, Geophys. Monogr. Ser., vol. 86, edited by D. C. Hurd and D. W. Spencer, pp. 83-86, AGU, Washington, D. C

Monaghan, E. J., and K. C. Ruttenberg (1999), Dissolved organic phosphorus in the coastal ocean: Reassessment of available methods and seasonal phosphorus profiles from the Eel River Shelf, Limnol. Oceanogr., 44, 1702-1714

Mopper, K., and K. G. Furton (1991), Analysis of sugars, chiral amino acids, and SFE-extractable lipids from POM, in Marine Particles: Analysis and Characterization, Geophys. Monogr. Ser., vol. 63, edited by D. C. Hurd and D. W. Spencer, pp. 151-162, AGU, Washington, D. C.

Orrett, K., and D. M. Karl (1987), Dissolved organic phosphorus production in surface seawaters, Limnol. Oceanogr., 32, 383-395.

Palenik, B., and S. T. Dyhrman (1998), Recent progress in understanding the regulation of marine productivity by phosphorus, in Phosphorus in Plant Biology: Regulating Roles in Molecular, Cellular, Organismic and Ecosystem Processes, edited by J. P. Lynch and J. Deikman, pp. 26-38, Am. Soc. of Plant Physiol., Rockville, Md.

Rengefors, K., K. Pettersson, T. Blenckner, and D. M. Anderson (2001), Species-specific alkaline phosphatase activity in freshwater spring phytoplankton: Application of a novel method, J. Plankton Res., 23, 435443

Rengefors, K., K. C. Ruttenberg, C. Haupert, C. Taylor, B. L. Howes, and D. M. Anderson (2003), Experimental investigation of taxon-specific response of alkaline phosphatase activity in natural freshwater phytoplankton., Limnol. Oceanogr., 48, 1167-1175.

Rigler, F. H. (1968), Further observations inconsistent with the hypothesis that the molybdenum blue method measured orthophosphate in lake water, Limnol. Oceanogr., 13, 7-13.

Ruttenberg, K. C., and S. T. Dyhrman (2004), Regulation and utilization of dissolved organic phosphorus in the coastal ocean, paper presented at ASLO/TOS meeting, Am. Soc. of Limnol. and Oceanogr., Honolulu, Hawaii.

Scanlan, D. J., and N. J. West (2002), Molecular ecology of the marine cyanobacteria Prochlorococcus and Synechococcus, FEMS Microbiol. Ecol., 40, 1-12.

Smith, S. V., W. J. Kimmerer, and T. W. Walsh (1986), Vertical flux and biogeochemical turnover regulate nutrient limitation of net organic production in the North Pacific Gyre, Limnol. Oceanogr., 31, 161-167.

Solórzano, L., and J. Sharp (1980), Determination of total dissolved phosphorus and particulate phosphorus in natural waters, Limnol. Oceanogr., $25,754-758$.

Solórzano, L., and J. D. Strickland (1968), Polyphosphate in seawater, Limnol. Oceanogr., 13, 515-518.

Wetz, J. J., and P. A. Wheeler (2005), Pump station data report for May 2001, August 2001 and January 2003 COAST cruises, Data Rep. 202, College of Oceanogr. and Atmos. Sci., Corvallis, Oreg.

Wu, J., W. Sunda, E. A. Boyle, and D. M. Karl (2000), Phosphate depletion in the western North Atlantic Ocean, Science, 289, 759-762.

K. C. Ruttenberg, Department of Oceanography and Department of Geology and Geophysics, SOEST, University of Hawaii, Honolulu, HI 96822, USA. (kcr@soest.hawaii.edu)

S. T. Dyhrman, Department of Biology, Woods Hole Oceanographic Institution, Woods Hole, MA 02543, USA. 